\title{
Population Ecology of the Desert Tortoise at Goffs, California
}

\author{
prepared for \\ Southern California Edison Company
}

by

Frederick B. Turner and Kristin H. Berry

\author{
University of California \\ Laboratory of Biomedical and Environmental Sciences \\ 900 Veteran Avenue \\ Los Angeles, California 90024
}

and

California Desert District Office

U.S. Bureau of Land Management

1695 Spruce Street

Riverside, California 92607

QL 


Population Ecology of the Desert Tortoise at Goffs, California

\author{
prepared for \\ Southern California Edison Company
}

by

Frederick B. Turner and Kristin H. Berry

\author{
University of California \\ Laboratory of Biomedical and Environmental Sciences \\ 900 Veteran Avenue \\ Los Angeles, California 90024
}

and

California Desert District Office

U.S. Bureau of Land Management

1695 Spruce Street

Riverside, California 92607

February 1984

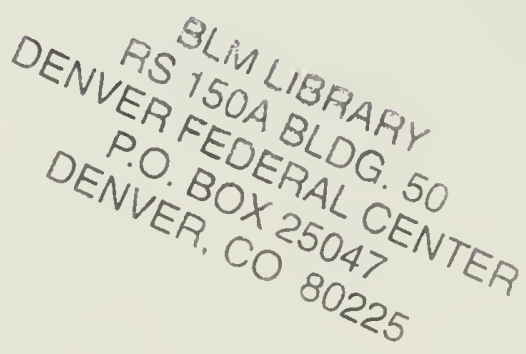





\section{Conclusions}

1. Some life-table parameters for the desert tortoise were successfully estimated in 1983: mortality of tortoises $\geq 180 \mathrm{~mm}$ long (2\%), clutch size (4.2), and clutch frequency (1.89). Reproduction in 1983 was probably substantially better than what would be typically observed because of heavy winter rain. Our estimate of nest destruction (23\%) is a minimal value because of obscuring effects of rains.

2. We were not able to derive an estimate of natural infertility of tortoise eggs because we never found an intact nest. Although we were able to register higher than usual proportions of tortoises $\leq 140 \mathrm{~mm}$ long (including 12 hatchlings), we did not obtain an estimate of mortality of small tortoises. 3. The outcome of the 1983 work strongly reemphasizes the same problem identified in our original proposal, viz., the difficulty in obtaining information relating to fates of eggs and early survival. In spite of the fact that we invested more than three times the effort typical of BLM-contracted research, we did not estimate two critical life-table parameters. Part of our problem follows from the fact that 1983 was our first season of work. We will be much better placed to estimate early mortality in 1984 . 



\section{Recommendations}

1. We have had trouble determining whether carcasses and remains are those of marked or unmarked tortoises. We must explore new methods of marking and/or labeling. Because it is important that even small portions of tortoises be recognized, use of injected ${ }^{45} \mathrm{Ca}$ or external dyes should be considered. 2. We must find a way to locate tortoise nests, so as to estimate natural infertility of eggs. This may be possible by intensive observation of females with radiotransmitters.

3. Continuing scrutiny of the Permanent Plot and the collection of tortoise remains should be a high priority endeavor, and the acquisition of repeated racords of large tortoises should be deemphasized.

4. Additional female tortoises should be fitted with transmitters. These tortoises should be matched in size, insofar as possible, with the observed size distribution in the Permanent Plot.

5. The amount of time spent seeking out nests destroyed by predators should be increased.

6. The feasibility of fitting tortoises $<100 \mathrm{~mm}$ long with small transmitters and batteries should be explored. This will involve weighing the customary trade-offs between range, battery size and battery life. 7. The possible use of a dog, or dogs, to assist in discovery of small tortoises should be pursued again during the spring of 1984 . 



\section{Executive Sumary}

furing the spring of 1993 we estahlished two $1-m i^{2}$ study areas near foffs, California. This locale is in eastern San Rernardino County, ahout 35 miles west of Needles. In one area (Plot 1) we examined the composition of the population and survival of its members. The other area (Plot 2) was used for investigations of egg production. Retween April 18 and nctoher 14, 1983, we registered $4 \Delta 1$ cesert tortoises in Plot 1 . Twelve of these were hatchlinus horn in late summer. If the other $429,110(26 \%)$ were <10n mm long, 103 (24\%) were 1:3-17? mm long, and $216(50 \%)$ were $>180 \mathrm{rm}$ in lenuth. The number of tortoisus $\geq 110 \mathrm{~mm}$ lnn? in the plnt was taken as 244 , hut we can only say that the density of srialler tortoises is at least $185 / r i^{2}$. The sex ratio did not differ significantly from $1: 1$.

Nineteen ferale tortnises in Plot 2 were perindically X-rayed hetween "av 1? and July 19. All produced one clutch of eggs and 15 laid a second clutch. One tortoise apparently produced a third clutch of 2 eggs. lean clutch? size (hased on 35 first and second clutches) :uas $4.17 \pm 0.22$, and mean clutch frequency was $1.839 \pm 0.11$. Clutch size was mositively correlated with hory sizr. Pecause of ohserved comlatory activity in autumn we $X$-rayen females again in September and loctoher. No egris were produced. Hy extrapolating our ohservations in Plot 2 to the breeding population in Plot 1 we estinated that Plot 1 females laid 796 eggs in 176 nests.

Searches of Plot 1 during the summer showed that at least 41 tortoise nests ( 23: $\left.{ }^{\prime}\right)$ were destroyed hy predators (principally kit foxes and hadgers). Seventy-twn carcasses were removed from Plot 1 during the 1983 season. Fiftynine of these were judged to reflect deaths since July 1982. lif estimated an 

age-constant annual death rate of $2 \%$ for tortoises $\geq 180 \mathrm{~mm}$ long. The evidence from other remains suggested a higher death rate among smaller tortoises, but was inconclusive.

Observations of predatory birds in Plot 1 increased from 0.05 per surveyhour to 0.12 per hour in June and 0.28 per hour in September and October. Potential predators observed were golden eagles, various hawks, roadrunners, burrowing owls, ravens and shrikes. Numbers of occupied kit fox dens in Plot 1 peaked at 5 in June. Recent scats of coyotes, foxes and badgers were another indicator of predator presence.

Dry weight production by annual plants in Plot 1 was estimated as about $40 \mathrm{~g} / \mathrm{m}^{2}(400 \mathrm{~kg} / \mathrm{ha})$. Schismus barbatus (an annual grass), borages (Pectocarya spp., Cryptantha spp.) and Lotus tomentellus (a legume) were the highest producers. Based on direct observations of feeding and analyses of scat contents, we concluded that tortoises favored herbs in the spring, but as these plants driet tortoises switched to grasses and parts of cacti. There was evidence of selection among herbs, and $37 \%$ of the feeding observations involving plants were of Lotus. Tortoises at Goffs also consumed soil, possibly as a calcium supplement. 



\section{Table of Contents}

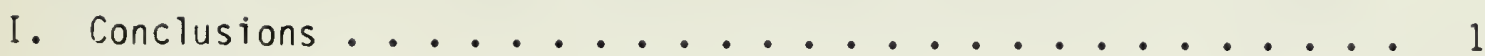

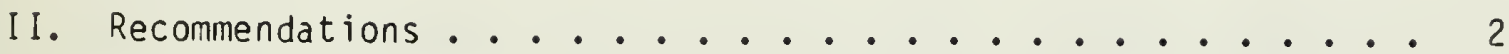

III. Executive Summary ................ 3

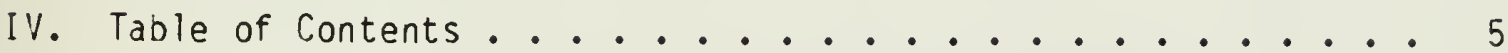

V. List of figures................. 6

VI. List of Tables and Appendixes ............ 6

VII. Introduction ............... 8

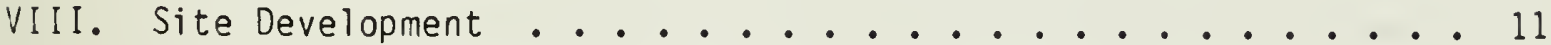

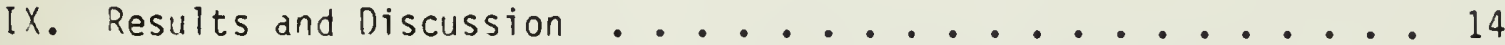

A. Rainfall and Air Temperatures .......... 14

B. Structure of the Plot 1 Population ........ 15

C. Density of the Plot 1 Population ......... 17

D. Egg Production by Tortoises in Plot 2....... 21

E. Mortality of Tortoises in Plot $1 \ldots . . . . .30$

F. A Hypothetical Life Table............ 35

f. Predators and Lagomorphs ............... 41

H. Abundance and Biomass of Annual Plants ....... 45

I. Feeding by Tortoises ............... 50

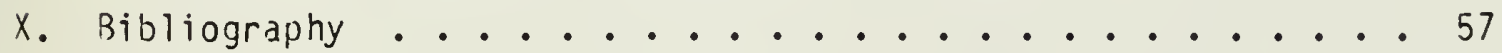

XI. Appendixes .................... 60 60

XII. Legal Notice and Acknowledgments ........... 62 



\section{List of Figures}

1. The desert tortoise (Scaptochelys agassizii).

2. General area map of study area in eastern San Bernardino County, Cal ifornia.

3. View of BLM Permanent Study Plot near Goffs, California (Plot 1).

4. Radiograph of a female desert tortoise with eggs.

VI. List of Tables and Appendixes

1. Air temperatures and rainfall at Goffs in 1983.

2. Size distribution and sex ratio of a sample of 384 desert tortoises registered in in 1983.

3. Comparison of size distributions of desert tortoises registered in 1980 and 1983.

4. Previous estimates of density of desert tortoises in Plot 1.

5. Capture-recapture data pertaining to desert tortoises $\geq 140 \mathrm{~mm}$ in size in 1983.

6. Clutch size and frequency among 19 female desert tortoises in Plot 2 in 1983.

7. Mean sizes and ranges in size of clutches laid in 1983.

8. Relationship of clutch size to body size among female tortoises in 1983.

9. Estimating egg production by the Plot 1 population in 1983.

10. Size distribution of remains of tortoises in 1983.

11. Recent remains of tortoises collected in 1983.

12. Provisional life-table parameters for the desert tortoise at Goffs.

13. Estimated production of female eggs by a cohort of 100 female desert tortoises over a period of 80 years.

14. Hypothetical stable age-distribution of a population of desert tortoises.

15. Comparison of hypothetical and observed age-distribution of tortoises.

16. Indicators of predator activity at Goffs in 1983.

17. Records of lagomorphs at Goffs in 1983. 

18. Estimated cover and frequency of annual plants in 1983.

19. Estimated net production by annual plants in 1983.

20. Dbservations of tortoise feeding at Goffs in 1983.

21. Numbers and sizes of scats of desert tortoises analyzed in 1983.

22. Common types of plant material in scats of tortoises at Goffs in 1983.

23. Concentrations of calcium, potassium and magnesium in soils collected at Goffs in 1978.

24. Concentration of 15 elements in soils collected at Goffs in 1983.

\section{Appendixes}

1. Comparisons of estimated coverage and frequency of annual plants in 1980 and 1983.

2. Estimated standing crops of annual plants in 1983. 



\section{Introduction}

Over the past 10 years the desert tortoise (Fig. 1) has emerged as a highly visible species--not only in California, but also throughout its range in the western U.S. (including parts of Arizona, Nevada and Utah). State and federal agencies have supported studies of local distribution, abundance and habitats. These studies have shown that some hahitats of the desert tortoise have been and are continuing to be seriously disturbed by human activities. Strong circumstantial evidence suggests that the abundance of the tortoise has declined in many parts of its range. Concern for the tortoise in southwestern Utah led to its listing as Threatened under the Endangered Species Act in 1979.

Causes of habitat disruption are manifold. One source of impacts--both past and present--is construction and maintenance of energy facilities. Development and transmission of energy involves construction and maintenance of gas-, water- and transmission-lines; roads, railroad spurs, wells, and power plants. The California Energy Commission recently identified the desert tortoise as the major biological issue associated with possible construction of a coal-burning power plant in Ivanpah Valley. The desert tortoise would also be a key issue if a $100 \mathrm{MW}$ solar thermal power plant were constructed in Johnson Valley.

Southern California Edison Company is now considering wind and solar energy projects that will require considerable amounts of land--some of which will be habitat of the desert tortoise. These projects may require several hundred square miles of lowland desert habitat over the next 20 years. The requirements for such facilities will impinge on tortoise habitat already strained by other land-use commitiments and demands. 



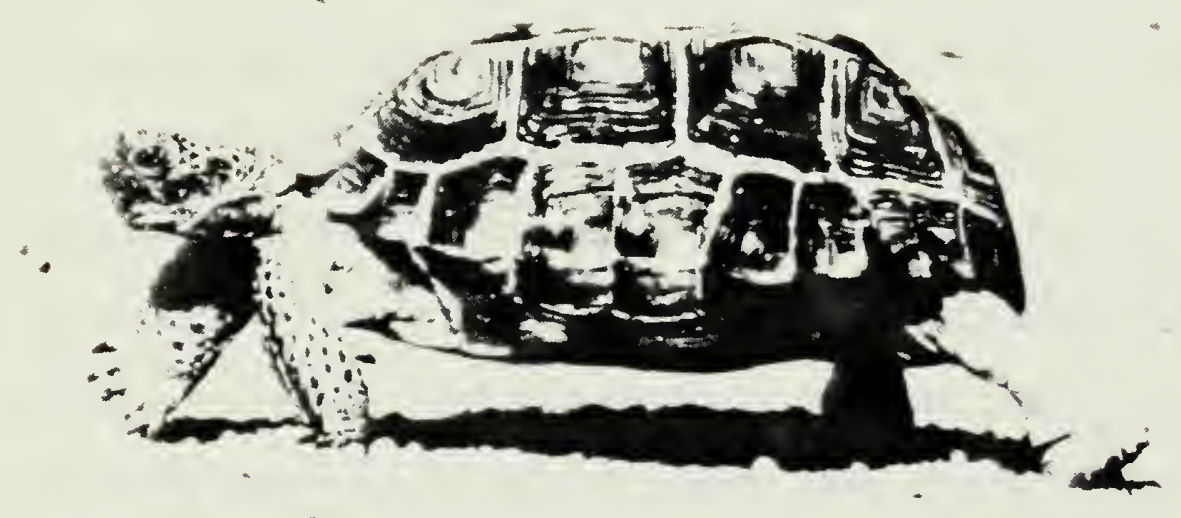

Fig. 1. The desert tortoise (Scaptochelys agassizii) 

The well-being of the tortoise will be an issue in connection with all future energy development projects within the species' geographic range. Utilities will be recurrently faced with questions as to likely consequences of new energy developments on the tortoise and how the effects of utility construction can be reduced or mitigated. For example, is it biologically defensible to relocate tortoises? If so, what are the most effective techniques and safeguards? Are there economically feasible ways in which tortoise habitat can be improved? Are there realistic procedures for protecting the quality of existing tortoise habitats? Attacking these questions requires, first, a sound understanding of the natural history of the tortoise and the dynamics of its populations and, second, the conduct of appropriately designed field experiments. This report describes field work during 1983 at a site in southeastern Califonia, where we are measuring naturally occurring rates of recruitment and mortality of desert tortoises, and how such schedules may be affected by extrinsic factors. We expect this project to provide an appropriate conceptual platform from which to design and carry out other tortoise-oriented studies related to siting and building energy facilities. 



\section{Site Development}

The site selected for our study is in Fenner Valley southwest of Goffs, Califonia, about 35 miles west of Needles and north of I-40 (Fig. 2). We worked in two $1-\mathrm{mi}^{2}$ areas. The first (PIot 1 ) is a BLM Permanent Tortoise Study Plot about 3-1/2 miles southwest of Goffs. The second (Plot 2) is about 7 miles southwest of Goffs. The elevation of this area is about $732 \mathrm{~m}$. Both plots are on public land.

The Permanent Study Plot has been used in earlier BLM studies in 1977 and 1980 (Burge; 1977, 1980). The plot lies on a bajada (2\% slope) with southern aspect (Fig. 3). The common perennial species are creosote bush, burro-bush, ratany, and various species of cholla cactus. Washes support smoke trees, catclaw, desert senna and joint fir. 0ld tracks of 4-wheel vehicles and tanks are evident and there is an old road traversing the area southwest to northeast. Cattle graze the plot in some years and have probably done so for 100 years, but usage in recent years apparently has been light. Plot 1 was used in investigations of death rates of various size groups of the population in 1983. Plot 2 was used to assess egg production by female tortoises.

The two study plots were prepared for spring field work between April 11 and 17, 1983. Plot 1 was located and one hundred $0.01 \mathrm{mi}^{2}$ quadrats established in a $10 \times 10$ rectilinear grid. Quadrats were permanently marked with numbered stakes, and six-foot laths with colored flagging were placed near the stakes so as to increase visibility. Plot 2 was located and its perimeter staked. Other reference points within this section were located and marked.

Field workers lived adjacent to the site, occupying their own vehicles. An air-conditioned motor home was rented in early June, moved to the site and used for one month. This unit was used as an office and a retreat from the extreme air temperatures experienced after 1000 hours. 


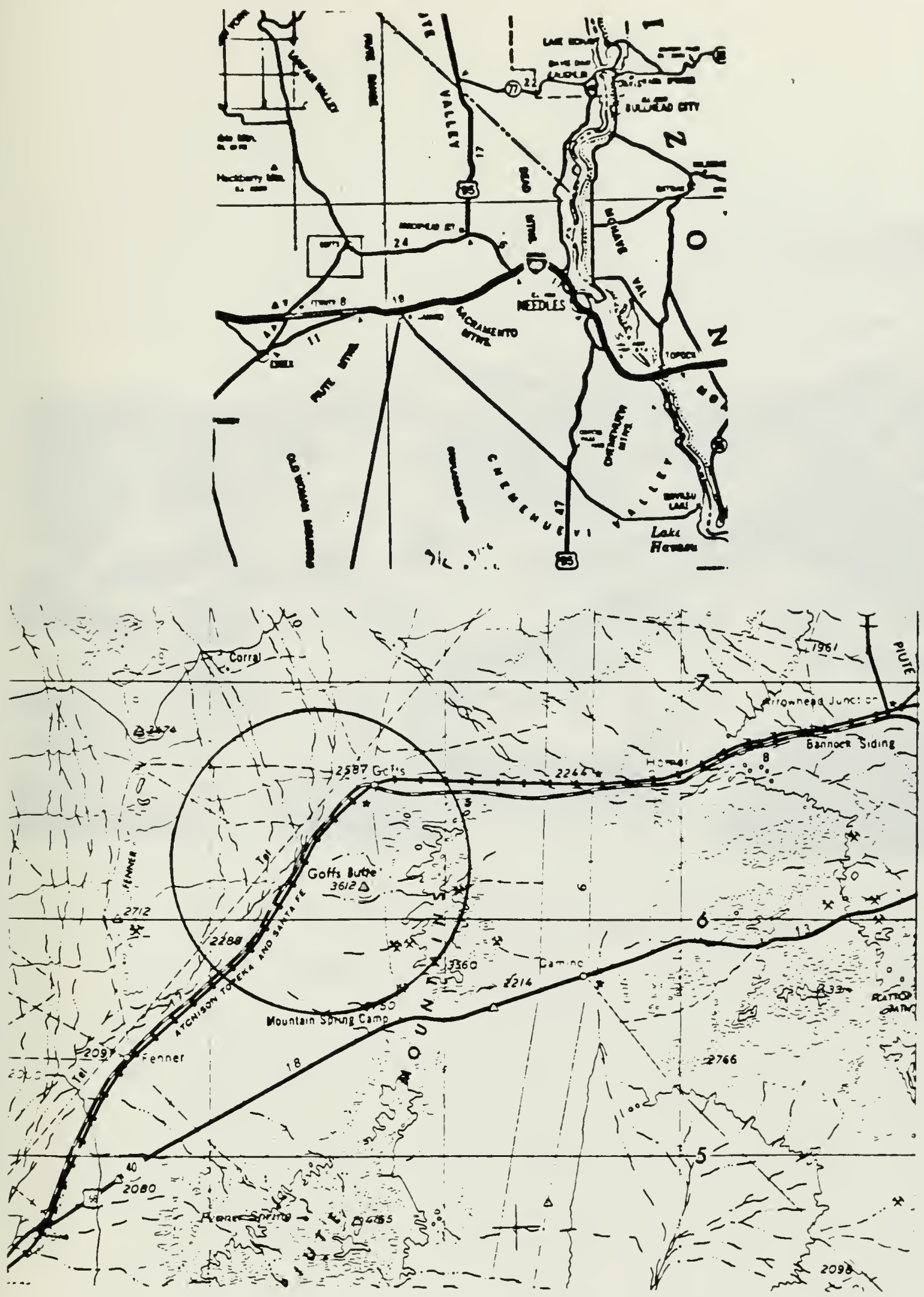

Fig. 2. General locale of study area in eastern San Bernardino County, California (above), and expanded view of Goffs area (below) 



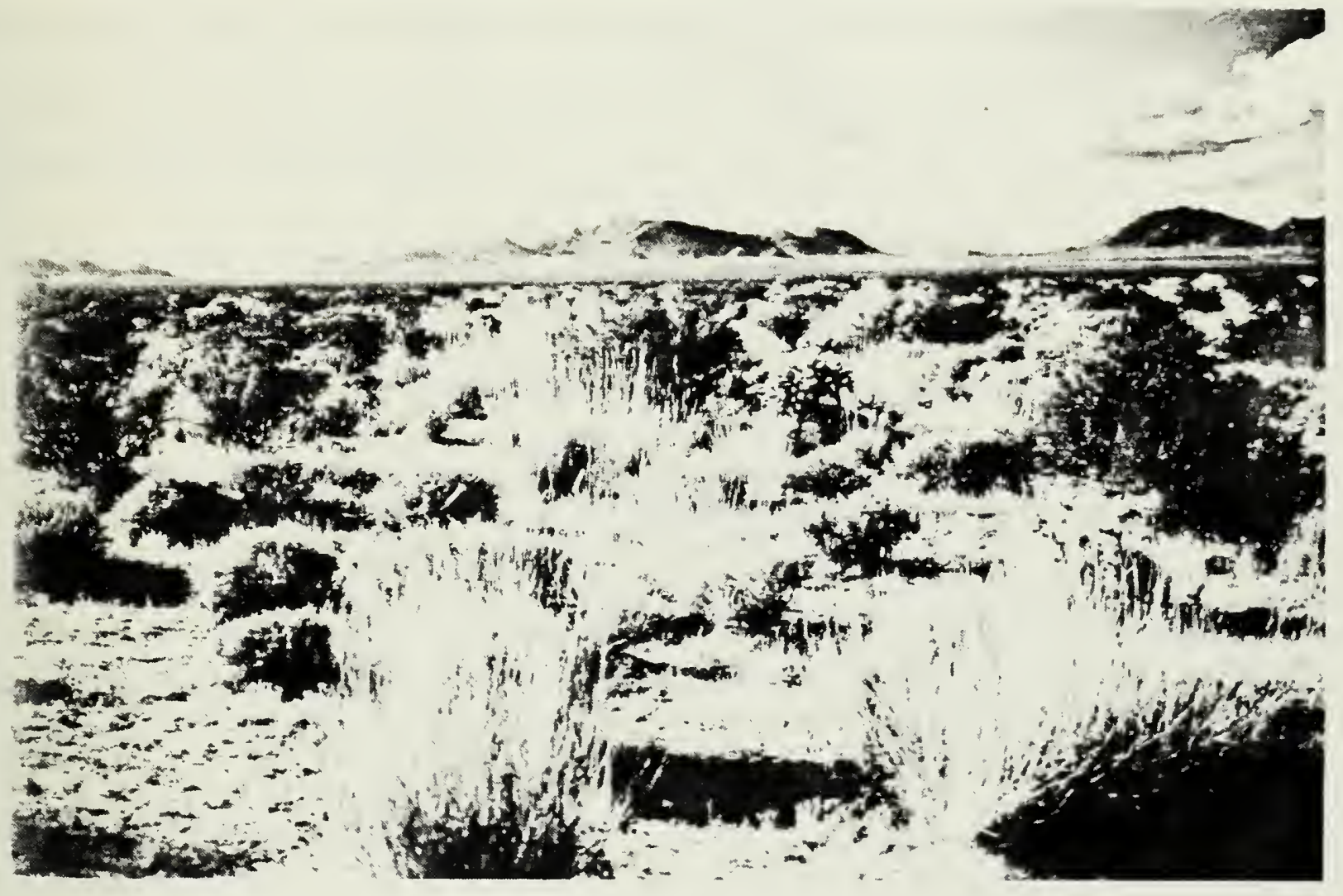

Fig. 3. View of BLil Permanent Study Plot (Plot 1) near Goffs, Cal ifornia 



\section{Results and Discussion}

A. Rainfall and Air Temperatures

Rain gauges were installed in the plots in late April 1983. Air temperatures were taken three times daily (0800, 1200 and 1800) and monthly mean temperatures computed from the sums of all readings. Table 1 summarizes meteorological observations.

Table 1. Air temperatures $\left({ }^{\circ} \mathrm{C}\right.$ ) and rainfall (mm) at Goffs in 1983

$\begin{array}{ccccc}\text { Dates } & \text { Mean air } & \text { Mean mid-day } & \text { Rainfall, } & \text { Rainfall, } \\ \text { temperature } & \text { air temperature } & \text { Plot 1 } & \text { Plot } 2\end{array}$

\begin{tabular}{lcccc}
\hline April 18-30 & 19.6 & 21.8 & $5^{1}$ & $5^{1}$ \\
ilay 1-31 & 28.2 & 29.4 & 0 & 0 \\
June 1-30 & 31.6 & 33.4 & trace & trace \\
July 1-August 3 & - & - & 41.4 & 9.7 \\
August 4-13 & 32.7 & 34.2 & 110.4 & 136.4 \\
Sept. 26-0ct. 14 & 23.4 & 25.4 & 71.1 & 52.1 \\
\hline
\end{tabular}

1estimated (rains occurred on April 18, 21 and 29)

Total annual rainfall at Goffs in 1967 and 1968 was 95.5 and $46.2 \mathrm{~mm}$, respectively (Department of Water Resources, 1981). We know of no other reliable sources of past rainfall data. Certainly the heavy rains between August 4 and Dctober 14, 1983, were extraordinary. 

B. Structure of the Plot 1 Population

Between April 18 and October 14 we registered 441 tortoises in Plot 1 (Table 2). Twelve of these were hatchlings entering the population in the late summer, and are not included in the table. The other 429 tortoises are representative of the population occupying this plot during the 1983 field season. However, because of extensive movements of some males the April-0ctober total is probably an overestimate of the population.

Table 2. Size distribution and sex ratio of desert tortoises registered in Plot 1 between April 18 and October 14, 1983

\begin{tabular}{|c|c|c|c|c|c|}
\hline Size class & $\begin{array}{l}\text { Size range } \\
\text { (Carapace } \\
\text { length, } \mathrm{mm} \text { ) }\end{array}$ & Not known ${ }^{1}$ & $\begin{array}{l}\text { Sex } \\
\text { Males }\end{array}$ & Females & Totals \\
\hline Juvenile 1 & $<60$ & 13 & & & 13 \\
\hline Juvenile 2 & $60-99$ & 97 & & & 97 \\
\hline Immature 1 & $100-139$ & 62 & & & 62 \\
\hline Immature 2 & $140-179$ & 41 & & & 41 \\
\hline Subadult & $180-207$ & 1 & 15 & 32 & 48 \\
\hline Adult 1 & $208-239$ & & 29 & 66 & 95 \\
\hline Adult 2 & $\geq 240$ & & 71 & 2 & 73 \\
\hline Totals & & 214 & 115 & 100 & 429 \\
\hline
\end{tabular}

${ }^{1}$ The sex of tortoises $<180 \mathrm{~mm}$ long cannot be reliably determined 

Tho size distrihution and sex ration reflected in Tahle 1 differ importantly from Similar data reported by Rurge (1980: Table 2), and it is worth considering these points in some detail. Tahle 3 contrasts size distributions of the 1980 and 1983 samnling.

Tahle 3. Size distributions of desert tortoises at finffs in 1980 (Burge, 1980) and 1983

\begin{tabular}{|c|c|c|}
\hline $\begin{array}{l}\text { Size classes } \\
\text { (and ranmes, min) }\end{array}$ & 1080 & 1983 \\
\hline$A+11)+s(20.3+)$ & 161 & 158 \\
\hline Sunadult.s $(180-207)$ & 2.5 & 43 \\
\hline Irimatures $(100-179)$ & 34 & 103 \\
\hline Juvenile $2(50)-99)$ & 20 & 97 \\
\hline Juvenile $1(\langle 60)$ & 6 & 13 \\
\hline Totals & 237 & 429 \\
\hline
\end{tabular}

These two distributions differ significantly $\left(x^{2}=39.3,4\right.$ d.f.), principally hecause relativelv more small tortoises (<100 mm long) were taken in 1983 . Chisquared totals for the illuenile 2 size-class contributed $70^{\alpha}$. of the total $x^{2}$ value. It is nossible that the age composition of the Goffs population changed hetween 1980 and 1983 , hut we helieve the difference simply reflects greater effort to find smaller tortnises in 1983. Rurqe worked alone in 1030 for ahout 51) tays: in 19.93 as many as four people searched for animals and the importance of small tortoises was emphasizen from the nutset. 

The sex ratio among tortoises $\geq 180 \mathrm{~mm}$ in length taken in 1983 (115 males, 100 females) does not differ from an assumed sex ratio of $1: 1$. However, Burge's 1980 sample was composed of 112 males and 74 females. This ratio differs from an assumed ratio of $1: 1\left(X^{2}=7.76, \underline{p}=<0.01\right)$. An analysis of census data from 18 BLM permanent study sites in California showed only four sites at which numbers of males and females differed significantly from a $1: 1$ ratio. Samples from the Argus Range and a portion of the Desert Tortoise Natural Area were composed predominantly of females. Samples from Goffs (1980) and Ward Valley contained significantly more males (Berry, 1984). Previous work at Goffs (1977 and 1978) resulted in a sample of 111 tortoises $\geq 180 \mathrm{~mm}$ in length (Burge, 1980: Table 2). Of these, 60 were males and 51 females. We have, then, two samples from foffs (1977-78 and 1983) showing no significant departures from a 1:1 sex ratio and one (1980) that does. The 1980 sample may have reflected an accurate, but transient, state of the population. For present purposes, however, we accept the 1983 sampling data as the most accurate representation of the state of the population.

C. Density of the Plot 1 Population

Burge (1980) estimated the density of tortoises at the Goffs plot in several ways (Table 4). All of her estimates related to the entire population of tortoises (all size classes) occupying the study area. In Table 4 her original estimates have been adjusted for the fact that her area was slightly larger than $1 \mathrm{mi}^{2}\left(1.03 \mathrm{mi}^{2}\right)$. Her 1980 capture-recapture data (Burge, 1980: Table 3) have been reanalyzed as suggested by Schumacher and Eschmeyer (1943). Paul Schneider analyzed Burge's 1980 capture-recapture data using the Stratified Lincoln Index (SLI). 

Table 4. Earlier estimates of the density of desert

tortoises in Plot 1 at Goffs

$\begin{array}{cc}\begin{array}{c}\text { Reference } \\ \text { Years }\end{array} & \text { Analytical } \\ \text { method }\end{array}$

Years

$$
\begin{aligned}
& \text { Population } \\
& \text { estimate }
\end{aligned}
$$

$\left(\mathrm{n} / \mathrm{mi}^{2}\right)$
$95 \%$ confidence

intervals
1977-1978 Proportional index, using 1977-78 sample and 1980 sample

Stratified Lincoln Index

1980
$447^{1}$

$371-522$

$502^{1}$

$410-615$

$417^{2}$

$353-501$

Index

Schumacher-Eschmeyer

Jolly-Seber (compensating

for immigration and

emigration)

1 from Burge (1980)

3 computed by Paul Schneider from Burge's data

recomputed from Burge's data

In 1983 we did not attempt to estimate numbers of tortoises less than $140 \mathrm{~mm}$ in length because of low recapture rates of smaller tortoises (see Schneider, 1980; Shields, 1980; Turner et al., 1984). We did carry out capturerecapture analysis of that portion of the Goffs population composed of larger tortoises. This analysis was based on four samples taken between April 18-May 15, May 16-18, May 30-June 1, and June 14-16. Other tortoises were registered between May 19 and 29, June 2 and 13, and after June 16, but these did not enter our analysis unless they were recaptured in a subsequent census period. During the first census period 157 tortoises $\geq 140 \mathrm{~mm}$ long were 

registered in $\mathrm{Plot} 1$. The subsequently acquired data were treated as a chain of samples, as described by Schumacher and Eschmeyer (1943). These figures are given in Table 5. In this table $\underline{x}_{t}$ is the number of marked tortoises at risk

Table 5. Capture-recapture data for desert tortoises $\geq 140 \mathrm{~mm}$ long in Plot 1 at Goffs in 1983

Dates

$$
\underline{x}_{t} \quad \underline{n}_{t} \quad \underline{x}_{t} \quad \underline{n}_{t} \underline{x}_{t}^{2} \quad \underline{x}_{t} \underline{x}_{t}
$$

May $16-18$

157

88

63

$2,169,112$

9,891

May 30-June 1

182

76

63

$2,517,424$

11,466

June $14-16$

195

91

81

$\underline{3,460,275} \quad \underline{15,795}$

$8,146,811 \quad 37,152$

just before the $\underline{t}_{t h}$ sample, $\underline{n}_{t}$ is the number of tortoises in the $\underline{t}_{t h}$ sample, and $\underline{x}_{t}$ is the number of marked tortoises in the $\underline{t}_{t h}$ sample. The estimate of the number of tortoises $\geq 140 \mathrm{~mm}$ in length is

$$
N=\sum \underline{n}_{t} \underline{x}_{t}^{2} / \Sigma \underline{x}_{t} \underline{x}_{t}
$$

or 219.3. Confidence ranges for the above estimate may be computed as described by DeLury (1958). First one calculates the standard deviation, s:

$$
(\underline{m}-1) \underline{s}^{2}=\sum \frac{\underline{x}_{t}{ }^{2}}{\underline{n}_{t}}-\frac{\left[\sum \underline{\underline{x}} \underline{\underline{t}} \underline{x}_{t}\right]^{2}}{\sum \underline{n}_{\underline{t}} \underline{x}_{\underline{t}}{ }^{2}}
$$



Here, $\underline{m}$ is 3 (or the total number of samples minus 1 ). Then,

$$
2 \underline{s}^{2}=0.000146
$$

and $\underline{s}=0.00854$. The $\underline{t}$-values for the $1 \%$ and $5 \%$ levels, with 3 degrees of freedom, are 5.84 and 3.18 , respectively. The endpoints for the confidence ranges are:

$$
\frac{\sum \underline{n}_{t} \underline{x}_{t}{ }^{2}}{\sum \underline{x}_{t} \underline{x}_{t} \pm \underline{t s} \sqrt{\sum \underline{n}_{t} \underline{x}_{t}{ }^{2}}}
$$

This gives endpoints of 218.5 and 220.1 (at the $1 \%$ level), and 218.8 and 219.7 at the $5 \%$ level.

We may now see (Table 2) that the total number of tortoises $\geq 140 \mathrm{~mm}$ long marked in 1983 (257) exceeds the capture-recapture density estimate (219). This is because some tortoises marked during the periods between censuses were not subsequently recaptured, and others were captured after mid-June. There is also the problem of immigration. Certainly some tortoises moved into Plot 1 during the course of our work, and these transients may have been recorded. This problem is particularly acute with males. Fortunately, the exact size of the Goffs population is not an immediate concern. The size of the population of breeding females is more important, and this group is less influenced by immigration (or emigration) Hence, while there is uncertainty as to the number of tortoises $\geq 140 \mathrm{~mm}$ in Plot 1 , we are probably not too far wrong in taking the 100 females $\geq 180 \mathrm{~mm}$ long (Table 2) as an estimate of the breeding population. We are even less certain as to numbers of tortoises <140 mm long (that part of 

the population we did not try to estimate), and can say only that we are dealing with a group exceeding 172 individuals.

D. Production of Eggs by Tortoises in Plot 2

We monitored egg production by tortoises in Plot 2 by $X$-irradiation (see Gibbons and Greene, 1979). Most of this work was carried out with female tortoises fitted with radiotransmitters. Radiotelemetry was necessary because subject females had to be recaptured and examined periodically. We used SB-2 low power (0.11-0.20 ma) transmitters provided by AVM Instrument Company. The transmitters had frequencies distributed between 150 and $152 \mathrm{mHz}$. Transmitters and batteries were housed in a specially fabricated fiberglass holder attached to the anterior portion of a female's carapace. A $3.2 \mathrm{~mm}$-wide copper foil loop antenna ( $1 / 4$ wave length) was also affixed to the carapace. A Telonics TR-2 receiver, a hand-held directional antenna, and a Telonics TDP-2 digital data processor completed our telemetry equipment.

Dur X-ray machine was a portable MinXray 300: a $30 \mathrm{~mA}-90 \mathrm{kV}$ unit with built-in electronic timer and collimator. The machine was mounted on a specially fabricated stand and used with commercial current at the Coffs store. We used 9-1/2" square medium speed Cronex X-ray film in metal cassettes. Our irradiation technique differed from that used by Gibbons and Greene (1979) in several respects. First, these authors conveyed tortoises to the laboratory and made X-rays with a stationary instrument. We used a portable instrument in the field. Gibbons and Greene used nonscreened cardboard cassettes at $200 \mathrm{~mA}$ and 70 $k V$ peak for 0.7 seconds ( $140 \mathrm{~mA}$-seconds). With our instrument we had to use metal cassettes. For the first month we used a setting of $20 \mathrm{~mA}$ and $80 \mathrm{kV}$ peak for 0.4 seconds ( $8 \mathrm{~mA}-\mathrm{sec}$ onds). In mid-June we changed the time to 0.25 seconds ( 5 mA-seconds) and obtained better prints. Film was developed at 

the Mohave Veterinary Clinic in Bermuda City, Arizona. Our procedure resulted in substantially lower radiation doses to tortoises, but our prints were not as clear as those obtained by Gibbons and Greene (1979: 87).

We did not receive batteries and transmitters as soon as we had planned, and the X-ray tube of our instrument blew out on May 11 when we attempted to use it in the field (with a generator as a power source). On 12-13 May 23 adult female tortoises were collected in Plot 2, taken to Bermuda City, X-rayed, and returned to be released at point of capture. Ten of these tortoises and 10 additional adult females were collected hetween 26-29 May. One of these tortoises had a carapace length of $189 \mathrm{~mm}$, 5 were between 191 and $200 \mathrm{~mm}$, 6 between 201 and $210 \mathrm{~mm}$, 5 between 211 and $220 \mathrm{~mm}$, and 3 were greater than $221 \mathrm{~mm}$. Transmitters were attached to these individuals. They were $X$-rayed at the Goffs store and released. One of these animals disappeared and was never retaken. The other 19 made up our experimental group. The general procedure was to locate a group of 4-6 animals in the late afternoon. The following morning these animals were collected, taken by car to the Goffs store ( 7 miles), $X$-rayed, returned to the plot, and released at points of collection. This process usually took about $3-4$ hours. These steps were repeated until all of the tortoises (or as many as could be found) had been processed. This procedure was repeated on 8-10 June, 19-21 June, 26-28 June, 3-5 July, 10-12 July, and $17-18$ July.

Figure 1 shows a representative X-ray taken on May 28. Four thicklyshelled eggs are clearly visible. The large central oval area is a chicken egg used to insure that exposure conditions were normal. Table 6 shows the history of 19 tortoises with transmitters between mid-May and mid-July. The interpretation of data in Table 6 is based on two points: first, the number of eggs counted in X-rays; and second, egg shell thickness. When two clutches of the 


same size were produced by the same female, we were still able to recognize that one clutch had been laid and another started (e.g., see Number 1077, 26-29 May and 8-10 June). In this instance the June eggs had very thin shells.

Inspection of 23 tortoises on May 12-13 showed that 13 (56\%) had started clutches of eggs. Judging from shell thicknesses, two of these clutches had just been shelled. Clutch size ranged from 1-10, with a mean of 4.3 . These were the first clutches of the season. Ten of these females were incorporated in our group of females fitted with transmitters when they were retaken on $26-$ 29. By July 3, $47 \%$ of females were still carrying oviductal eggs. On July 18 only one tortoise of 19 examined had eggs, and this was a clutch started in late June. The total interval of egg production (early May to July 18) was certainly sufficient for the development of three clutches, but in only one instance did our data suggest that this occurred (Number 1061).

We estimated mean clutch frequency (1.89) by dividing the total estimated number of clutches laid (36) by the number of females laying them (19). All females laid a first clutch, 16 of 19 apparently laid a second, and one a third. The mean size of the first clutch (4.1) did not differ significantly from the mean size of the second (4.3), and the overall mean clutch size was 4.2 . The range in clutch size was from 1 to 7 (Table 7). Clutch sizes were positively correlated with female body size, and this was true whether one examined first clutches, second clutches, or a 11 clutches combined (Table 8). The 

Table 6. Clutches of eggs produced by 19 desert tortoises at Goffs in 1983. Underlining indicates different clutches

Tortoise Carapace May May June June June July July July Clutch number length 12-13 26-29 8-10 19-21 26-28 3-5 10-12 17-18 frequency (mm)

\begin{tabular}{|c|c|c|c|c|c|c|c|c|c|c|}
\hline 1004 & 205 & & 3 & 0 & 2 & 2 & 0 & 0 & 0 & 2 \\
\hline 1005 & 233 & & 6 & 6 & 0 & 7 & 7 & 7 & 0 & 2 \\
\hline 1007 & 198 & & 6 & 6 & 0 & 0 & 0 & 0 & 0 & 1 \\
\hline 1026 & 218 & & 5 & & & 3 & 0 & 0 & 0 & 2 \\
\hline 1027 & 204 & & 4 & 4 & 0 & 4 & 4 & 4 & 4 & 2 \\
\hline 1041 & 206 & 4 & 4 & 4 & 4 & 0 & 0 & 0 & 0 & 1 \\
\hline 1059 & 216 & 0 & 4 & 0 & 6 & 6 & 6 & 0 & 0 & 2 \\
\hline 1061 & 215 & 4 & 5 & 5 & 2 & 2 & 2 & 0 & 0 & 3 \\
\hline 1063 & 197 & 0 & 3 & 3 & 4 & 4 & 4 & 0 & 0 & 2 \\
\hline 1064 & 198 & 4 & 4 & 0 & 0 & 0 & 0 & 0 & 0 & 1 \\
\hline 1065 & 216 & 3 & 0 & 6 & 6 & 0 & 0 & 0 & 0 & 2 \\
\hline 1067 & 191 & 0 & 3 & 4 & 4 & 4 & 0 & 0 & 0 & 2 \\
\hline 1071 & 202 & 0 & 4 & 0 & 5 & 5 & 5 & 0 & 0 & 2 \\
\hline 1072 & 192 & 0 & 3 & 3 & 0 & 4 & 4 & 0 & 0 & 2 \\
\hline 1073 & 248 & 6 & 5 & 6 & 0 & 0 & 0 & 0 & 0 & 2 \\
\hline 1077 & 216 & & 4 & 4 & 4 & 0 & 0 & 0 & 0 & 2 \\
\hline 1078 & 189 & & 2 & 1 & 1 & 1 & 0 & 0 & 0 & 2 \\
\hline 1079 & 201 & & 5 & 5 & 0 & 0 & 3 & 3 & 0 & 2 \\
\hline 1084 & 227 & & & 5 & 4 & 4 & 4 & 0 & 0 & 2 \\
\hline
\end{tabular}



Table 7. Mean sizes and ranges in size of clutches produced in Plot 2 at Goffs in 1983

\begin{tabular}{lcccc}
\hline Clutches & $\underline{n}$ & $\begin{array}{c}\text { Percent of } \\
\text { females laying }\end{array}$ & $\begin{array}{c}\text { Mean size } \\
\text { one standard } \\
\text { error of mean }\end{array}$ & $\begin{array}{c}\text { Range in } \\
\text { size }\end{array}$ \\
\hline First & 19 & 100 & $4.10 \pm 0.26$ & $2-6$ \\
Second & 16 & 84 & $4.25 \pm 0.39$ & $1-7$ \\
All & 35 & - & $4.17 \pm 0.22$ & $1-7$ \\
\hline
\end{tabular}

Table 8. Correlation coefficients and F-values for tests of non-zero slopes in regressions of clutch sizes on body sizes of female desert tortoises at Goffs in 1983

$\begin{array}{lllll}\text { Clutches } & \begin{array}{l}\text { Range of female } \\ \text { body size }(\mathrm{mm})\end{array} & \underline{F} & - & F_{-0.01}\end{array}$

\section{First}

Second

A 11
$189-248$

0.65

$189-248$

0.62

0.63

$189-248$
12.5

8.3

8.8

8.7

21.8

7.4 

equation for predicting clutch size (C) from carapace length (IICL, Inm) hased on all 35 clutches in Table 7 is:

$$
\underline{C}=0.1754 \underline{1 \mathrm{ICL}}-7.22
$$

This predicts a clutch size of around 3.1 for a $190 \mathrm{~mm}$ female and a clutch size of 5.7 for a female $238 \mathrm{~mm}$ lnng.

Eqns in $2 f$ clutches were measured in $x$-rays taken llay $12-13$ and llay $28-29$. Clutch sizes ranjed from two to 10 . lleasurements taken were the "length," or 7aximal dimensinn and the "width," at right anqles to the first dimension. :Ee calculated a mean egg size intex (MESI) by multiplying the two dimensinns of each eqg in a clutch, sumning the products, and dividing by clutch size. Females hearing clut.ches ranned in size from 189 to $248 \mathrm{~mm}$ in carapace length. I'ESI values were regressed nn fernale body size. The F-test of non-zero slope (3.2) Mas statistically insignificant (d.f. 1, 25). Hence, these data shnwed no evitence of a relationship hetween eng size and ferlale hody size.

Conulation of desert tortoises has been reported in Arizona during the fall (Tomkn, 1972), and this hehavior was conspicunusly evident in nur study areas hetween late summer and nctoher 1983. Many courtship rings were ohserved in plot 1. Between mid-July and mid-Septemher $82 \%$ of 17 females examined were "nounted by one or more males. Temporary identification numbers were written with a permanent rarking pen on the epoxy covering the antenna encircling each female's carapace. The numbers were on the fifth vertebral--at the rear of the caranace. "umbers vere often obscured by vertical abrasion. Judying from this evidence, ahout $40 \%$ of females were mounted hetween 20 Septemher and 13 October. Seven females apparently copulated during both intervals. He have nn evidence 

that insemination occurred during these incidents, although Tomko reported discharge of fluids from the cloaca of the female tortoise he observed. Seventeen tortoises were $X$-rayed between 19-21 September and 11-13 October and no shelled eggs were evident in radiographs.

If viable sperm can be retained by females over winter, fall copulation may simply serve to increase the probability of insemination of every mature female. Or autumnal copulation may promote bonds between particular males and females. Whatever purpose is served, there is no evidence that eggs are produced in fall.

All of the 19 X-rayed females were sexually mature and produced at least one clutch of eggs. The smallest female in our sample was $189 \mathrm{~mm}$ long. We adopt this value as the size at sexual maturity, although we recognize that not all females become mature at the same size. Future measurements will help to clarify this source of variation. Our group of 19 female tortoises with transmitters ranged in size from 189 to $248 \mathrm{~mm}$ in length, but 16 of these were $\leq 220 \mathrm{~mm}$ long. The mean size of females in Plot 2 was about $200 \mathrm{~mm}$. The size distribution of 100 females $\geq 180 \mathrm{~mm}$ long registered in Plot 1 ranged from 180 to $247 \mathrm{~mm}$. We excluded 7 individuals less than $189 \mathrm{~mm}$ long and computed a mean size for the remaining $93(216 \mathrm{~mm})$. The tortoises $x$-rayed were, then, somewhat smaller than the Plot 1 breeding population. To compensate for this, we used Equation (4) relating clutch size to body size to estimate egg production by the Plot 1 females (Table 9). This shows that these 93 females could have been expected to lay about 421 eggs (first clutch) and then another 375 eggs in second clutches $(421 \times 0.89)$. These estimates do not make allowance for growth of females between the laying of the first and second clutches. It is also assumed that the likelihood of producing two clutches is not size-dependent. The 796 eggs laid would have been deposited in 176 nests. 

Table 9. Estimated egg production by 93 sexually mature desert tortoises in Plot 1 at Goffs during 1983

\begin{tabular}{|c|c|c|c|}
\hline $\begin{array}{l}\text { Mid-point of size } \\
\text { interval (mm) }\end{array}$ & $\begin{array}{l}\text { Number of } \\
\text { females }\end{array}$ & $\begin{array}{l}\text { Mean clutch } \\
\text { size }\end{array}$ & $\begin{array}{c}\text { Eggs laid } \\
\text { (first clutch) }\end{array}$ \\
\hline $190^{1}$ & 1 & 3.10 & 3.10 \\
\hline 193 & 5 & 3.26 & 16.30 \\
\hline 198 & 6 & 3.53 & 21.18 \\
\hline 203 & 6 & 3.81 & 22.86 \\
\hline 208 & 11 & 4.08 & 44.88 \\
\hline 213 & 12 & 4.35 & 52.20 \\
\hline 218 & 13 & 4.62 & 60.06 \\
\hline 223 & 18 & 4.89 & 88.02 \\
\hline 228 & 13 & 5.16 & 67.08 \\
\hline 233 & 4 & 5.43 & 21.72 \\
\hline 238 & 3 & 5.71 & 17.13 \\
\hline $247^{1}$ & 1 & 6.20 & 6.20 \\
\hline Totals & 93 & & 421 \\
\hline
\end{tabular}

lactual body size, no interval mid-point 

E. Iortality of Tortoises in Plot 1

Pre-natal mortality. Between mid-liay and July 1, August 3-13, and late September and early October, we searched Plot 1 for signs of nest destruction by nredators. Mestruction of clutches was inferred from both excavated nests and rendins of eqg shells. During June, we located 18 nests excavated by kit foxes, coyntes, hadgers and possibly other predators. Predation was attributed to foxes in five cases, harigers in four, and to coyotes in one instance. restroyers of the other nests could not he determined. Between July 1 and linust 3 when the next survey was bequn, 41.4 mon of rain fell. This obscured much of the activity by predators. During the 11-day August survey, 21 nests and ogra shell clusters vere discovered. The August survey period was folloned hy extraordinarily heavy rains, hut in spite of their effects two additional excavated nests vere located in Sentemher and lctober. At least 41 nests, then, Here destroyed hy predators. We have assumed that no egrys survived these tepretations, although one intact egy was found in one opened nest. If 176 nests were laid and 41 destroyed, we can estimate the minimal rate of nest testruction in 1083 as $23^{\prime \prime}$.

Lampkin (1956) stated that. it is not unusual for half the eggs laid by captive fomale desert tortoises to be infertile. Legler (1960) reared 60 eggs of hox turtles in the laboratory and found $15(25 \%)$ to be infertile. However, nnly $35(3 n \%)$ of the 45 fertile eggs hatched. We never located an intact nest with eggs, sn we have no measure of natural infertility. For present purposes we vill assume $55 \%$ of eggs laid (and not destroyed) hatch.

If nest destruction is independent of the number of eggs in the nest ve can estimate that of 796 eggs laid, 183 were testroyed hy predators. Df the remaining 513 , we estimate that about 405 hatched at some time during the autumn of 1383. 

Death-rates of tortoises. During the 1983 season we removed 72 carcasses or other remains of tortoises from Plot 1 (Table 10). Five of these remains were in scats, and of these four were of small tortoises ( $\leq 102 \mathrm{~mm}$ long).

Table 10. Size distribution of remains of tortoises taken at Goffs in 1983

Size

classes

Juvenile 2

Immature 1

Immature 2

Subadult

Adult 1

Adult 2

Totals
Not known

Male

Sex

Female
7

38

14

0

2

2

61
2

2

5

4

7

If Plot 1 was completely cleared of remains in 1980 and again in 1983, and if no carcasses were removed from or brought onto the plot during this interval, the figures in Table 10 provide estimates of numbers of death among size groups whose members were alive in 1980 (all but the Juvenile 1 category). The 1980 Stratified Lincoln Index analysis provided estimates of the numbers of tortoises alive in 1980, viz., 76 juveniles, 138 immatures, 40 subadults, and 163 adults.

A $x^{2}$-test of numbers of tortoises presumed to have survived and died among the immature, subadult and adult size classes is statistically insignificant $\left(x^{2}=1.75,2\right.$ d.f. $)$. That is, if we take these values at face value, there is no support for estimating anything other than a common rate of 

survival for all size groups, viz., 314/341, or 0.92 . The deaths are presumed to have occurred over a 3-year period, and if we assume that survival was constant over this interval we can estimate annual survival (스) as:

$$
e^{-3 \lambda}=0.9208
$$

Hence, the annual survival rate is about $97.3 \%$.

The validity of this estimate rests on the conditions set forth on the previous page, as well as the reliability of the SLI estimates of various size components of the 1980 population. We consider the foregoing procedure reasonable for subadult and adult tortoises (i.e., those $\geq 180 \mathrm{~mm}$ long) hecause 1) carcasses of tortoises this size are fairly conspicuous and do not disintegrate readily (Woodman and Berry, 1984; Berry and Woodman, 1984), and 2) the SLI estimates of numbers are reliable. The picture is less clear for immature tortoises, because smaller remains are harder to see, disintegrate somewhat more rapidly, and are probably more readily displaced. A conservative approach to the numbers in Table 10 would be to estimate a 3 -year survival rate for only subadults and adults (190/213). The annual rate derived from this value is $97.8 \%$, essentially the same as the previous rate. Berry and Woodman (1984) estimated an annual death rate of $1.2 \%$ for adult tortoises at Goffs between June 1972 and June 1980, based on remains collected in 1977, 1978 and 1980. This estimate spanned an 8-year interval because the time of death of some of the carcasses could be placed as much as 5 years in the past. We can split out more recent deaths among the 72 remains collected in 1983 (Table 11). If one adult among an estimated group of 168 (see Table 2) 

Table 11. Remains of tortoises judged to

have died after July 1, 1982

\begin{tabular}{lcc}
\hline Size classes & $\begin{array}{l}\text { July } 1,1982- \\
\text { June } 30,1983\end{array}$ & $\begin{array}{c}\text { July } 1- \\
\text { October } 14,1983\end{array}$ \\
\hline Juvenile 1 & 1 & 5 \\
Juvenile 2 & 22 & 11 \\
Immature 1 & 9 & 0 \\
Immature 2 & 0 & 1 \\
Adult 1 & 0 & \\
\hline
\end{tabular}

died in 3-1/2 months, we can convert this to an annualized death-rate of $2 \%$, or a survival rate of $98 \%$. This is about what the analysis of all carcasses showed. However, the figures pertaining to smaller tortoises suggest a problem. Table 10 shows that remains of 59 juvenile and immature tortoises were collected in 1983, and Table 11 shows that 50 of these were judged to have died since July 1982. This could be taken as evidence that roughly 5.5 times as many deaths occurred between July 1982 and mid-October 1983 than between the summer of 1980 and July 1982. We consider it more likely, however, that these data simply reinforce the idea that remains of small tortoises are not as persistent as those of older individuals (Woodman and Berry, 1984). Hence, the data in Table 11 are a better estimate of death rates among smaller tortoises. The problem is that we do not know how many small tortoises were alive in the spring of 1982 , i.e., there is nothing to which the 50 deaths can be related. If we want to assume that the 1982 population was like the 1980 population, and accept 

the SLI density estimates of 76 juveniles and 138 immatures, we could estimate a 16-1/2 month survival rate of $164 / 214(77 \%)$ among these tortoises ( $82.5 \%$ per year). There is, then, some suggestion in Table 11 that death-rates among smaller tortoises exceed those of older tortoises. This would not be at all surprising, and has been shown to be true among Chrysemys picta in Michigan (Wilbur, 1975; Tinkle et al., 1981). However there are so many uncertainties with respect to numbers of smaller tortoises and our ability to find their remains, that we must leave the issue of early mortality open for now. 

F. A Hypothetical Life-Table

Table 12 summarizes the present status of our knowledge of the Goffs desert tortoise population.

Table 12. Life-table parameters for the desert

tortoise at Goffs, California based on work in 1983

Parameters

Estimated

Remarks

values

Sex ratio

Female age at

maturity

Female body size at maturity

Reproductive lifetime

Mean clutch size

Clutch frequency

Pre-natal mortality

due to predation

Losses due to natural Not known infertility of eggs

or failure to develop

Mortality from hatching Not known

to ensuing spring

Annual mortality rate Not known to size of $180 \mathrm{~mm}$

Annual mortality rate of larger females

(assumed age-constant)

$189 \mathrm{~mm}$

4.2

\section{1:1 Typical of most California populations}

Not known Usually assumed to be $15-20$ years

Not known Captive females $\geq 80$ years old have laid eggs

1.89 Probably approaching maximal capacity; certainly above modal performance

Minimal estimate for 1983

$50 \%$ infertility of eggs of captive tortoises has been reported
$2 \% \quad$ Not an unusual estimate, but higher rates have been reported 

As pointed out, a few samples of desert tortoise populations (including one from Goffs in 1980) exhibit statistically significant departures from a $1: 1$ ratio of males to females. Nevertheless, the preponderance of evidence, including other samples from Goffs, indicates that male and female tortoises $\geq 180 \mathrm{~mm}$ in length are equally abundant. This is not to say that temperaturedependent sex determination does not occur. According to Ian Swingland (pers. comm.) all of the European tortoises exhibit this phenomenon (Testudo hermanni, I. graeca, I. marginata and I. horsefieldi), and both Swingland and Richard Vogt (pers. comm.) believe the same will prove true of the desert tortoise. We will assume, however, that the probabilities of male and female hatchings are the same.

For present purposes we will assume an age of 20 years for the attainment of sexual maturity by females at Goffs. The clutch frequency estimated (1.89) derived from 1983 sampling is probably higher than would normally occur. Turner et al. (in press) estimated clutch frequencies of 1.1 (1981) and 1.6 (1980) in Ivanpah Valley, California. For present purposes we will use a mean clutch frequency of 1.5 . This means that each reproductively mature female will, on average, produce 6.3 eggs in a season, with the potential for 3.15 female hatchlings. The mortality parameters in Table 12 have already been discussed. We will assume a maximum life-span of 100 years.

We have enough information to make a provisional estimate of the life-time egg production (and potential female offspring) of a cohort of 100 females which have attained the age of 20 years. These figures are shown in Table 13 . Here we have combined numbers of survivors at the midpoint of 5-year intervals. 

Table 13. Estimated production of female eggs by a cohort of 100 female desert tortoises over a period of 80 years

\begin{tabular}{|c|c|c|c|c|}
\hline $\begin{array}{l}\text { Age range } \\
\text { (years) }\end{array}$ & $\begin{array}{l}\text { Midpoint } \\
\text { (years) }\end{array}$ & $\begin{array}{l}\text { Number of females } \\
\text { in age interval }\end{array}$ & $\begin{array}{l}\text { Individual female } \\
\text { egg production }\end{array}$ & $\begin{array}{l}\text { Total egg } \\
\text { production }\end{array}$ \\
\hline $\begin{array}{l}20-25 \\
25-30 \\
30-35 \\
35-40 \\
40-45 \\
45-50 \\
50-55 \\
55-60 \\
60-65 \\
65-70 \\
70-75 \\
75-80 \\
80-85 \\
85-90 \\
90-95 \\
95-100\end{array}$ & $\begin{array}{l}22 \\
27 \\
32 \\
37 \\
42 \\
47 \\
52 \\
57 \\
62 \\
67 \\
72 \\
77 \\
82 \\
87 \\
92 \\
97\end{array}$ & $\begin{array}{l}480.5 \\
434.5 \\
393.5 \\
356.0 \\
322.0 \\
291.5 \\
263.5 \\
238.5 \\
216.0 \\
195.5 \\
176.5 \\
160.0 \\
144.5 \\
131.0 \\
118.5 \\
107.0\end{array}$ & 3.15 & $\begin{array}{l}1,514 \\
1,369 \\
1,240 \\
1,121 \\
1,014 \\
918 \\
830 \\
751 \\
680 \\
616 \\
556 \\
504 \\
455 \\
413 \\
373 \\
337\end{array}$ \\
\hline Totals & & 4,029 & & 12,691 \\
\hline
\end{tabular}

Table 13 shows that over an 80-year reproductive period a cohort of 100 females would lay 12,691 female eggs. If the population is--over the long-term-stable, only 100 females will attain sexual maturity from these eggs. We do not know that the Goffs population is stable, but for the purposes of completing a provisional life-table we will assume numerical equilibrium.

Table 12 shows that at least $23 \%$ of eggs laid are destroyed by predators, and we have also assumed (p. 27) that only $66 \%$ of the eggs escaping this fate will hatch. Hence, $50.8 \%$ of the 12,691 eggs will add 6,447 female hatchlings to the population. But this number will dwindle, over the course of 20 years, to 100. We have no existing information as to how this mortality is distributed 

over the period of youth and adolescence. Early mortality, say, that occurring over the first 5-6 years of life is probably heavier than that occurring after the shell of the tortoise is fully hardened. However, we will simply assume that the death-rate $(\underline{\lambda})$ is constant between hatching and the attainment of sexual maturity. Then:

$$
\mathrm{e}^{-20 \lambda}=100 / 6,447
$$

Then $\underline{\lambda}=0.208$, and the annual death rate over the first 20 years is estimated as about 19\%. Because we are assuming a population in equilibrium, the stationary age distribution is equivalent to the distribution of survivors, and we can see what the age distribution of such a population would look like (Table 14). In this table we also attempt to relate ages to ranges in body size, although this can only be done acccurately for the first three yearclasses (tortoises 1,2 and 3 years old). 

Table 14. Hypothetical stable age-distribution of a population of desert tortoises

\begin{tabular}{lcr}
\hline $\begin{array}{c}\text { Age range } \\
\text { (years) }\end{array}$ & $\begin{array}{c}\text { Size class and approximate } \\
\text { body size (mm) }\end{array}$ & $\begin{array}{c}\text { Percent of } \\
\text { population }\end{array}$ \\
\hline $0-1$ & Juvenile $1(<60)$ & 17.1 \\
$1-2$ & Juvenile 2, Immatures & 13.7 \\
$2-3$ & $(60-179)$ & 11.1 \\
$3-4$ & Subadults (180-207) & 9.0 \\
$4-5$ & Adults (208+) & 21.5 \\
$11-10$ & & 7.0 \\
$16-20$ & & 2.5 \\
$21-100$ & & 10.7 \\
\hline
\end{tabular}

No sampling distribution of desert tortoises resembling that in Table 14 has ever been reported. While Table 14 illustrates a population composed of about $42 \%$ Juvenile 1 tortoises, the highest reported value in California is about 11\% (Berry, 1984). Table 15 contrasts the hypothetical distribution in Table 14 with mean proportions of tortoises reported for 17 populations in California (Berry, 1984) and with the distribution we observed at Goffs in 1983 (see Table 2). The means of 17 populations were computed by summing the percentages for each size class and dividing by 17 . 

Table 15. Comparison of hypothetical and observed age-distributions of tortoises

\begin{tabular}{|c|c|c|c|c|}
\hline Size class & $\begin{array}{c}\text { Postulated age } \\
\text { range (years) }\end{array}$ & $\begin{array}{l}\text { Hypo- } \\
\text { thetical }\end{array}$ & $\begin{array}{l}\text { Mean of } 17 \\
\text { California } \\
\text { populations } \\
\text { (Berry, 1984) }\end{array}$ & $\begin{array}{l}\text { Goffs } \\
1983\end{array}$ \\
\hline
\end{tabular}

\begin{tabular}{lcccc}
\hline Juvenile 1 & $1-3$ & 0.419 & 0.037 & 0.030 \\
$\begin{array}{c}\text { Juvenile 2 } \\
\text { and Immatures }\end{array}$ & $3-15$ & 0.449 & 0.324 & 0.466 \\
Subadults & $16-20$ & 0.025 & 0.127 & 0.112 \\
adults & $21+$ & 0.107 & 0.512 & 0.392 \\
\hline
\end{tabular}

Low proportions of Juvenile 1 tortoises may reflect actual absence of recruitment or inability to record these individuals in proportion to their actual numbers (Shields, 1980; Schneider, 1980). To account for the discrepancy between the 1983 sample at Goffs and the hypothetical distibution would require the addition of at least 300 Juvenile 1 tortoises to the actual registry given in Table 2, and even then adult tortoises would still make up $23 \%$ of the population.

An alternative explanation of the Goffs 1983 sampling data is that Juvenile 1 tortoises really are poorly represented in the population. If this be true we would then have to conclude that 1) the Goffs population is declining in numbers (not evident from sampling between 1980 and 1983), or that 2) those tortoises which hatch survive very well until sexually mature. 

The foregoing exercise merely emphasizes what was apparent from the summary presented in Table 12, viz., that particular efforts must be focused on the dynamics of the first three year-classes.

\section{G. Predators and Lagomorphs}

Mortality of desert tortoises varies from year to year, but the reasons for this are not known. Woodbury and Hardy (1948) commented: "The predator pressure on tortoise probably varies from time to time. Perhaps it is correlated with the rabbit cycle. Rabbits...were very abundant [in southwestern Utah] during the years 1941 and 1942, but the cycle reached a low from 1943 to 1946. During late 1945 and early 1946, tortoise fatalities obviously due to carnivores showed an increase when compared with the few such signs observed earlier. Perhaps the tortoise is subjected to a greater amount of...pressure from bobcats and coyotes when the usual food--rabbits--is scarce." Berry (1975) stated that the China Lake tortoise population experienced losses of 21 to 28\% in the winter of 1972-73 because of canid predation ( $c f$. an estimated annual loss rate of only 5\% during the previous year). Turner et al. (in press) reported $4.4 \%$ annual mortality in $1980-81$ and $18.7 \%$ mortality in 1981-82. In none of these earlier studies were any data relating to the abundance of predators or rabbits presented.

As part of our work at Goffs we are making simple observations of the relative abundance of predators and rabbits, so that observed year-to-year changes in death rates may be more clearly interpreted. Almost all potential predators observed were birds, but only one of 72 dead tortoises found in 1983 appeared a possible victim of avian predation. Most dead tortoises appeared to have been killed by canids or badgers. These animals were rarely seen, so we recorded indirect signs of the presence and abundance of these predators, e.g., 

dens and numbers of scats. Observations of predatory birds and signs of mammals are given in Table 16.

Table 16. Indicators of predator activity

in Plot 1 at Goffs in 1983.

\begin{tabular}{|c|c|c|c|c|c|}
\hline Indicators & April & May & June & August & Sept.-0ct. \\
\hline $\begin{array}{l}\text { Observations of } \\
\text { avian predators per } \\
\text { survey-hour }\end{array}$ & 0.05 & 0.09 & 0.12 & 0.09 & 0.28 \\
\hline $\begin{array}{l}\text { Golden Eagle } \\
\text { Red-tailed Hawk } \\
\text { Kestrel } \\
\text { Other hawks } \\
\text { Roadrunner } \\
\text { Burrowing Owl } \\
\text { Raven } \\
\text { Shrike }\end{array}$ & $\begin{array}{l}x \\
x\end{array}$ & $\begin{array}{l}x \\
x \\
x\end{array}$ & $\begin{array}{l}x \\
x \\
x\end{array}$ & $\begin{array}{l}x \\
x \\
x\end{array}$ & $\begin{array}{l}x \\
x \\
x \\
x \\
x \\
x\end{array}$ \\
\hline $\begin{array}{l}\text { Number of occupied } \\
\text { kit fox dens }\end{array}$ & 4 & & 6 & 3 & 1 \\
\hline Total dens observed & 33 & & 37 & 37 & 39 \\
\hline $\begin{array}{l}1983 \text { predator scats } \\
\text { Coyotes } \\
\text { Kit foxes } \\
\text { Badgers and others }\end{array}$ & $\begin{array}{r}16 \\
104 \\
7\end{array}$ & & $\begin{array}{r}27 \\
441 \\
5\end{array}$ & $\begin{array}{r}6 \\
296 \\
0\end{array}$ & $\begin{array}{r}26 \\
59 \\
0\end{array}$ \\
\hline
\end{tabular}

Thirty-nine kit fox den complexes were identified in Plot 1 during the spring and summer. Fourteen dens showed signs of use. Five of these were occupied by families of foxes for one to several weeks. In general, kit foxes showed an increased activity at dens in June (only 4 dens were used by foxes in May). Three of six badger burrows showed signs of activity, and another two burrows of unidentified large mammals were also in use. Seventeen predator scat concentration areas were identified during the 1983 season. 

Kit fox dens were not uniformly dispersed over Plot 1. Of 39 dens, 13 were in the northwest quarter, 15 in the northeast quarter, 8 in the southwest quarter, and 3 in the southeast quarter. If nests were dispersed homogeneously, one would expect 9.75 in each quarter. A test of this expectation gives a $x^{2}$-value of $8.9\left(x_{0.05}^{2}=7.8\right)$. We believe the non-homogeneous dispersion of dens is probably related to the highway running from southwest to northeast along the southeastern corner of Plot 1 . If one divides the section by diagonal lines into four equal areas (i.e., two triangular areas in the northwestern and southeastern corners, and two central strips between), 17 of 39 observed fox dens were in the northwestern corner and only 5 in the southeastern corner-closest to the highway. The $x^{2}$-test of this dispersion also gave a significant value $\left(x^{2}=8.1\right)$.

In searching for evidence of tortoise nest destruction we found unequivocal remains of 36 nests and 5 cases of indirect evidence (i.e., shell fragments). The excavated nests were distributed in the same manner as the fox dens, i.e., 12 in the northwest quarter, 15 in the northeast quarter, 2 in the southeast quarter, and 7 in the southwest quarter of Plot $1\left(X^{2}=10.9\right)$. Dividing the section into two corners and two diagonal strips also indicated a nonhomogeneous dispersion of excavated nests $\left(x^{2}=8.2\right)$.

Burge (1980) has al ready commented on the apparent low density of tortoises in the southeast corner of Plot 1. She called attention both to the highway as well as possibly important differences in both perennial and annual plants in various parts of the section. Our analyses of dispersions of tortoises in this plot are not complete, but what has been done seems to confirm Burge's earlier findings. In summary, both kit fox dens and tortoises are more prevalent in the northern half, or northwestern quarter, of Plot 1 . There is more evidence of destruction of tortoise nests in these parts of the plot. The ultimate 

causations are unclear, but it seems reasonable to postulate that more nests are constructed in areas of higher tortoise abundance, and that incidence of nest destruction is simply proportional to numbers of nests.

Table 17 gives observations of lagomorphs (principally jackrabbits) at Goffs in 1983.

Table 17. Records of lagomorphs on or in the vicinity of Plot 1 during 1983.

\begin{tabular}{lcc}
\hline Dates & $\begin{array}{r}\text { Lagomorphs per } \\
\text { survey-hour } \\
\text { (Plot 1) }\end{array}$ & $\begin{array}{c}\text { Lagomorphs per } \\
\text { 1/2-hour drive } \\
\text { (paved road) }\end{array}$ \\
\hline April 18-30 & 0.02 & 0.50 \\
May 1-31 & 0.10 & 0.23 \\
June 1-30 & 0.15 & 2.60 \\
August 3-13 & 0.26 & 2.67 \\
September 26 & 0.29 & 0.38 \\
October 14 & & \\
\hline
\end{tabular}


- 
H. Abundance and Biomass of Annual Plants in Plot 1

Annual plants were sampled along two 100-m transects on April 12-13 and again on May 18-19, 1983. Locations and orientations of these lines (I and II) were described by Burge (1980). Twenty-five sampling points were established at equal intervals along these transects and annual plants examined in quadrats at each point. Visual estimates of coverage by major species were made using $20 \times 50 \mathrm{~cm}\left(0.1 \mathrm{~m}^{2}\right)$ quadrats. Data from 25 quadrats were then combined to estimate mean coverage $\left(\mathrm{cm}^{2} / \mathrm{m}^{2}\right)$, relative coverage, frequency (proportion of quadrats in which various species occurred), and relative frequency along each transect. Procedures followed were similar to those used in sampling annuals along Transect I in 1980 (Burge, 1980).

We also estimated biomass of major species along each transect in April and May. Quadrats $\left(1 \mathrm{~m}^{2}\right)$ were established at 25 points along each line and plants growing in all (or portions) of these areas were collected, sorted, and placed in paper bags. Species of Pectocarya were not segregated. Areas collected within $1 \mathrm{~m}^{2}$ quadrats varied from the entire area (for uncommon species) to subquadrats as small as $0.1 \mathrm{~m}^{2}$ (for species like Pectocarya and Schismus). Plants collected were oven-dried at $70^{\circ} \mathrm{C}$ for 100 hours and then weighed. Estimated standing crops were computed by dividing total dry weights of species (or species groups) by the total area examined for each species (e.g., $2.5 \mathrm{~m}^{2}$ for Schismus barbatus; $25 \mathrm{~m}^{2}$ for Lepidium Iasiocarpum). On October 10, all annual plants growing in $250.1-\mathrm{m}^{2}$ quadrats along each transect were collected and placed in paper bags. This material was oven-dried and weighed. Total standing crops were estimated by dividing total dry weights by $2.5 \mathrm{~m}^{2}$.

Appendix 1 contrasts measurements along Transect I made in 1980 (Burge, 1980) and 1983. Total estimated coverage in 1980 (27.2\%) and 1983 (25.3\%) were about the same, but while over 90\% of 1983 coverage was by Schismus barbatus 

this grass contributed only about $76 \%$ of cover in 1980 . Borages and Lotus tomentellus were relatively more prominent in 1980.

Table 18 gives coverage and frequency data for both transects in April and May. The floras of the two transects--at least as revealed by our sampling-were not at all similar. An index of similarity $(\underline{S})$ was computed for the two transects:

$$
\underline{S}=2 \underline{C} /(\underline{A}+\underline{B})
$$

where $\underline{A}$ is the number of species on the first transect, $\underline{B}$ is the number of species on the second transect, and $\underline{C}$ is the number of species common to both transects. The value of $\underline{S}$ was only 0.38 . About twice as many species were recorded along Transect II as on Transect I, and the Transect II flora was more diverse. Total estimated coverage along Transect I was higher than that along Transect II because of the abundance of the grass, Schismus barbatus, along Transect I.

As would be expected, both coverage and frequency declined between midApril and mid-May. Estimated cover declined about 19\% along Transect I, roughly $31 \%$ along Transect II. Estimated frequency of annuals was reduced $22 \%$ along both transects. Rankings of various species were generally stable between April and May, with a grass ( Transect I, and a co-dominant (with various species of Pectocarya) along Transect II. Species richness declined somewhat along both transects. 

Table 18. Estimated cover and frequency of annual plants along two transects in $\mathrm{Plot} 1$ in 1983

$$
\text { Cover }\left(\mathrm{cm}^{2} / \mathrm{m}^{2}\right)
$$

Relative Frequency

cover (\%)
Relative

Frequency

Transect Species April May April May April May April May

I. Schismus

\begin{tabular}{|c|c|c|c|c|c|c|c|}
\hline barbatus & 2316 & 1822 & 91.5 & 89.2 & 1.00 & 1.00 & 34.7 \\
\hline$\frac{\text { Lotus }}{\text { tomentellus }}$ & 135 & 140 & 5.3 & 6.9 & 0.72 & 0.68 & 25.0 \\
\hline$\frac{\text { minutiftora }}{\text { Lepidium }}$ & 17 & 39 & 0.7 & 1.9 & 0.28 & 0.16 & 9.7 \\
\hline Erodium & 10 & 18 & 0.4 & 0.9 & 0.20 & 0.16 & 6.9 \\
\hline$\frac{\text { cicutarium }}{\text { Others }}$ & $\begin{array}{r}7 \\
46\end{array}$ & $\begin{array}{l}10 \\
14\end{array}$ & $\begin{array}{l}0.3 \\
1.8\end{array}$ & $\begin{array}{l}0.5 \\
0.6\end{array}$ & $\begin{array}{l}0.12 \\
0.56\end{array}$ & $\begin{array}{l}0.08 \\
0.16\end{array}$ & $\begin{array}{r}4.2 \\
19.4\end{array}$ \\
\hline Totals & 2531 & 2043 & 100 & 100 & 2.88 & 2.24 & 100 \\
\hline
\end{tabular}

II Schismus

barbatus 732

Pectocarya spp. 807

$\begin{array}{lllllll}542 & 43.6 & 46.6 & 1.00 & 1.00 & 18.0 & 23.2\end{array}$

Styloctine

$\begin{array}{lllllll}546 & 48.1 & 47.0 & 1.00 & 1.00 & 18.0 & 23.2\end{array}$

micropoides 51

Chorizanthe

$\begin{array}{llllll}3.0 & 1.5 & 0.56 & 0.60 & 10.1 & 13.1\end{array}$

Eriophyllum

6

16

0.4

$\begin{array}{lll}1.3 & 0.28\end{array}$

0.24

$5.0 \quad 5.6$

pringlei

$\begin{array}{lllllll}11 & 1.6 & 1.0 & 0.64 & 0.36 & 11.5 & 8.3\end{array}$

Lepidium

27

Cryptantha

8

$8 \quad 0.5$

$\begin{array}{lll}0.7 & 0.40 & 0.28\end{array}$

$8.6 \quad 6.5$

angustifolia

$7 \quad 0.4$

0.6

0.32

0.20

5.8

4.6

C. $\frac{\text { circumscissa }}{\text { others }}$

$4 \quad 0.4$

$0.3 \quad 0.28$

0.24

5.0

5.6

11

$2.0 \quad 1.08$

0.40

18.0

9.9

Totals

100

$\begin{array}{lllll}100 & 5.56 & 4.32 & 100 & 100\end{array}$ 

Appendix 2 gives estimated standing crops of various annuals along two transects in April and May, and aggregate standing crop estimated in October. Because annual species reach peak vegetative development at different times of the season, the best way to estimate net production is to take the higher standing crop value for each species. Table 19 gives production estimates derived in this manner from data in Appendix 2. Productivity was essentially the same in both parts of Plot 1 sampled, although relative contributions of various species differed. The grass, Schismus barbatus, was the dominating component in both areas. Schismus and various species of Pectocarya made up about $94 \%$ of total estimated net production along Transect II, while Schismus and Lotus tomentellus composed $91 \%$ of total production along Transect I. 

Table 19. Estimated production $\left(g / \mathrm{m}^{2}\right)$ by annual plants

along two transects in Plot 1 in 1983

Species

Astragalus didymocarous

Chorizanthe brevicornu

Cryptantha angustifolia

C. circumscissa

Eriogonum trichopes

Eriophyllum pringlei

E. wallacei

Erodium cicutarium

Eschscholtzia minutiflora

Lepidium lasiocarpum

Lotus tomentellus

Lup inus concinnus

Pectocarya spp.

Schismus barbatus

Stylocline micropoides

Others

Totals
Transect I

Transect II
0.20

0.02

0.10

0.50

0.07

0.23

0

0.10

0.11

0.23

0

0.43

0.01

0.17

0.13

$<0.01$

1.07

0.02

1.29

0.21

7.60

0.12

0.21

0.67

0.54

13.55

31.20

24.22

$<0.01$

0.21

0.13

0.11 



\section{Feeding by tortoises}

Feeding habits of tortoises were inferred from two kinds of data: direct observation, and analysis of scats. Table 20 recapitulates 123 observations of tortoises of various sizes between mid-April and August 13, 1983. The soil ingestion data will be discussed separately.

Direct observations showed an overwhelming tendency towards the consumption of two leguminous species (Lotus tomentellus and Lupinus concinnus) during the early part of the season. Lotus tomentellus was well represented along Transect I but scarcely present in samples along Transect II (Tables 18 and 19). In 1980 Burge made 100 observations of tortoises feeding on plants and 72 of these involved consumption of Lotus tomentellus (Burge, 1980).

Schismus barbatus was extremely abundant on both transects, but was essentially ignored as a source of food between April 18 and May 25. After the end of May most feeding observations were of $\underline{s}$. barbatus (including dried remains) and of parts of cacti (usually Opuntia ramosissima). These findings are similar to those reported by Turner et al. (in press) in Ivanpah Valley in 1980 when annual plants made up about 19\% of the diet between April 1 and May 30 but only $9 \%$ of diets between June 9 and July 18. Use of grasses and cacti increased from about $62 \%$ in the early part of the season to $82 \%$ later on. Hohman and Ohmart (1980) also reported increased consumption of perennial grasses and shrubs as green forb availability declined.

Scats of tortoises were collected in Plot 1 between April 15 and June 30,1983 . We took care to collect only material clearly referable to the 1983 season, which could be judged from color and consistency. Scats were separated into groups collected between April 15-30, May 1-15, May 16-31, 

Table 20. Observations of tortoise feeding at Goffs in 1983. Upper lines for each item refer to period of April 18-May 25; lower lines to May 26-August 13

Sex and size (mm) of tortoises

Items consumed $\leq 100 \quad 101-179 \quad$ Male $\geq 180 \quad$ Female $\geq 180 \quad$ Totals

\begin{tabular}{|c|c|c|c|c|c|}
\hline$\frac{\text { Schismus }}{\text { barbatus }}$ & $\begin{array}{l}1 \\
2\end{array}$ & $\overline{5}$ & $\overline{7}$ & $\overline{7}$ & 21 \\
\hline$\frac{\text { Hilaria }}{\text { rigida }}$ & - & $\overline{1}$ & $\overline{2}$ & $\overline{2}$ & $\begin{array}{l}0 \\
5\end{array}$ \\
\hline$\frac{\text { Erodium }}{\text { cicutarium }}$ & 1 & - & - & $\bar{j}$ & 1 \\
\hline$\frac{\text { Lotus }}{\text { tomentellus }}$ & $\begin{array}{l}4 \\
-\end{array}$ & $\begin{array}{l}4 \\
1\end{array}$ & $\begin{array}{r}11 \\
1\end{array}$ & 17 & $\begin{array}{r}36 \\
2\end{array}$ \\
\hline$\frac{\text { Lupinus }}{\text { concinnus }}$ & $\overline{2}$ & $\overline{1}$ & $\begin{array}{l}3 \\
1\end{array}$ & $\begin{array}{l}2 \\
1\end{array}$ & $\begin{array}{l}5 \\
5\end{array}$ \\
\hline$\frac{\text { Pectis }}{\text { papposa }}$ & - & - & - & $\bar{z}$ & $\begin{array}{l}0 \\
2\end{array}$ \\
\hline Cryptantha spp. & - & - & $\overline{1}$ & $\begin{array}{l}1 \\
1\end{array}$ & $\begin{array}{l}1 \\
2\end{array}$ \\
\hline Other herbs & $i$ & - & $\begin{array}{l}1 \\
-\end{array}$ & $\overline{1}$ & $\begin{array}{l}1 \\
2\end{array}$ \\
\hline Opuntia spp. & - & - & $\begin{array}{l}1 \\
8\end{array}$ & $\overline{5}$ & $\begin{array}{r}1 \\
13\end{array}$ \\
\hline Scats & $\overline{1}$ & - & $i$ & - & $\begin{array}{l}0 \\
2\end{array}$ \\
\hline Soil & $\begin{array}{l}4 \\
2\end{array}$ & $\begin{array}{l}2 \\
3\end{array}$ & $\begin{array}{l}1 \\
4\end{array}$ & $\begin{array}{l}5 \\
1\end{array}$ & $\begin{array}{l}12 \\
10\end{array}$ \\
\hline Totals & 18 & 17 & 42 & 46 & 123 \\
\hline
\end{tabular}



Table 21. Scats of desert tortoises collected

in 1983 and analyzed for contents

Time periods

Large scats

n Mean weight $(g)$
Small scats

n Mean weight $(g)$

\begin{tabular}{lcccc}
\hline Apri1 15-30 & 8 & 3.5 & 20 & 1.5 \\
May 1-15 & 30 & 3.0 & 30 & 0.9 \\
May $16-31$ & 10 & 4.2 & 20 & 1.6 \\
June $1-15$ & 5 & 4.5 & 8 & 2.2 \\
June $16-30$ & 4 & 6.4 & 7 & 1.8
\end{tabular}

June 1-15 and June 16-30, and further subdivided into large scats and small scats (Table 21). All scats were ground with a Wiley mill and the ground material thoroughly mixed. Five $g$ of material from each of 10 time-size groups were examined by the Composition Analysis Laboratory at Colorado State University. Slides were prepared and five subsamples of 20 fields were analyzed for each sample. Items in scats were identified by comparisons with standards on file, and relative frequencies (and standard deviations) of various items computed.

Items in scats included various grasses (e.g., Aristida, Bouteloua, Hilaria and Schismus), occasional parts of perennial shrubs (e.g., Ambrosia), parts of cacti, various annual plants (e.g., Astragalus, Camissonia, Cryptantha, Erodium, Lotus, Lupinus), various seeds, and a few parts of arthropods. 

Although some statistically significant differences existed between frequencies of particular food items in large and small scats, there was no apparent pattern to these differences. Furthermore, such differences were rare when comparisons involved common food items. Hence, we have combined data from the two size groups of scats in Table 22. These findings are generally similar

Table 22. Common types of plant material (relative frequencies, \%) in scats of tortoises at Goffs in 1983

Type of Food

Time periods

$\begin{array}{lllll}\text { Apri1 } & \text { Hay } & \text { May } & \text { June } & \text { June } \\ 15-30 & 1-15 & 16-31 & 1-15 & 16-30\end{array}$

Hilaria rigida

8.8

6.3

1.0

0.9

Schismus barbatus

8.2

14.4

17.0

28.0

17.7

cactus

61.0

14.5

13.1

61.6

78.5

legumes 1

15.1

63.7

67.3

4.3

0.2

others

6.9

1.1

2.6

5.1

2.7

\section{'Lupinus, Lotus}

to the observations of feeding (Table 21), in that grasses and cacti replaced annual plants in diets after annual plants dried out.

As shown in Table 20, tortoises of all sizes were observed ingesting soil all through the 1983 season. This behavior is not unusual, and was reported in Arizona (Hohman and Ohmart, 1980), at Goffs (Burge, 1980) and at the Desert Tortoise Natural Area near California City (Marlow and Tollestrup, 1982). 

'owevar, the frequency with which this behavior has been observed at forffs is Inrthy of note. The purpose of geophagy is not clear, although hoth Sokol (1n71) and Marlow and Tollestrup argue that the ingestion of soil may provide a valuahle calcium supplement to diets.

Tortoises at fonfs feed unon soil scraped from the hanks of washes and from areas in the open desert. Fecal pellets composed almost snlely of soil may he fnund throughout. the area. Such nellets are much more dense than those cornosed of mlant narts. Two scats of roughly the same size weighed 2.2 and 3.? ?; the former was composed almost entirely of sand.

Soils at roffs were collected hy RLll personnel in 1978 and analyzed by Bahenck? Snns in Piverside. These samples were analyzed for Ca, ing and $k$ (Tahle 23). Concentrations of these elements were always relatively low at

Tahle 23. Mean concentrations (ppr) of three elements in snils collected at lioffs site in 1973. Ranges of ohservations are given in parentheses

$\begin{array}{lll}\text { Flements } & \text { Soils from five } & \text { Soils from four } \\ \text { "eating" sites } & \text { other sites }\end{array}$

Ca

113

$(9-225)$

K 33

$(1-120)$

11
385

$$
(18-1400)
$$

13

$(6-26)$

4

26 $(21-36)$ 

sites not, known to he used as a source of soils, but were sometimes low and sometirmes high at 'feeding' sites. In fact, two of the latter (which provided the lowest values for the three elements measured) were not--in general--much different from the other sites.

:Arlow and Tollestrup (1982) compared amounts of calcium in soils consumed hy tortoises with arounts in soils ingested. Calcium concentrations in

In samples of soils excavated and consumed hy tortoises ranged from 1.0 to $2.13 \%$ $(1 n, n() n$ to $28,(0 n n) \Gamma m)$. Calcium concentrations in samples of surface soil not !I sed hy tontonises ranged from 350 to 1,000 ppm.

In June 198,3 we made further analyses of elemental concentrations in lioffs snils. Snils were collected in three situations: an actively mined area in a Wash bank, a nearhy area with a wite evaporite on the surface, and an area ?1!0 "l alay in the open dosert where no evidence of soil ingestion was ohserved. Snils rere passed through a 15 -mesh sieve to remove rocks and fragments of verpetation. Sieved material was transferred to 1 liter plastic hottles and placed in mechanical mixer for t:un hours. Three 25-g aliquots of mixed soil from each of three collection sites were weighed and transferred to clean plastic hottles. Then $100 \mathrm{cc}$ of $0.1 \mathrm{~N} \mathrm{HCl}$ was added to each hottle, and the hot,tles placed in the mixer for 30 minutes. The samples were centrifuged at 1?,000 rpm for 10 min with a Sorvall SS-3 Automatic Centrifuge. The supernate was poured off into fresh plastic bottles and this material was analyzed with an Applied Research Laboratories $1.5 \mathrm{~m}$ direct reading optical emission spectrometer. Excitation was by inductively coupled plasma (ICP). We analyzed for 15 elements, following a list of 'essential' elements fiscussed by ilertz (1931). Tahle 24 gives concentrations of these elements (ppm) in soils ingested by tortoises (columns 2 and 3 ) and soils apparently not consumed (column 4). 

Sodium, calcium, strontium and vanadium are present in higher concentrations in soils sought out by tortoises. We do not believe the latter two elements have any relevance to this behavior. The choice is less clear between $\mathrm{Ca}$ and $\mathrm{Na}$. Although calcium is present in fairly high concentrations in desert vegetation $(\sim 2 \%)$, Marlow and Tollestrup review several kinds of evidence that tortoises may have unusually high calcium requirements. Sodium is not as concentrated in desert annuals (generally $<1 \%$ ), but is also an important dietary requirement. Whether the ingestion of soils is solely for calcium or sodium or for both, cannot be definitely ascertained from existing analyses.

Table 24. Estimated concentrations (ppm) of 15 elements in soils from three situations at Goffs

$\begin{array}{lcc}\text { Elements } & \text { Mvaporite } & \text { Open Desert } \\ \text { area } & & \text { Drea }\end{array}$

\begin{tabular}{lrrr}
\hline $\mathrm{Na}$ & 84 & 185 & 24 \\
$\mathrm{Ca}$ & 990 & 1073 & 343 \\
$\mathrm{~K}$ & 15 & 18 & 50 \\
$\mathrm{P}$ & 27 & 26 & 65 \\
$\mathrm{Mg}$ & 38 & 37 & 44 \\
$\mathrm{Zn}$ & 0.7 & 0.5 & 0.6 \\
$\mathrm{Cu}$ & 0.4 & 0.4 & 0.4 \\
$\mathrm{Fe}$ & 4.4 & 3.5 & 7.2 \\
$\mathrm{Mn}$ & 5.0 & 7.5 & 5.7 \\
$\mathrm{~V}$ & 0.24 & 0.22 & 0.06 \\
$\mathrm{Si}$ & 771 & 745 & 804 \\
$\mathrm{Cr}$ & 0.12 & 0.13 & 0.10 \\
$\mathrm{Ni}$ & 0.23 & 0.25 & 0.20 \\
$\mathrm{Sr}$ & 5.9 & 5.9 & 2.3 \\
$\mathrm{Se}$ & 1.0 & 1.1 & 1.0 \\
& & & \\
\hline
\end{tabular}





\section{Bibliography}

Berry, K. H. 1975. The desert tortoise relocation project: status report for

1974. Report to Division of Highways, State of California. 26 pp.

Berry, K. H. (ed.). 1984. The status of the desert tortoise (Gopherus

agassizi) in the United States. Report from the Desert Tortoise Council to

the U.S. Fish and Wildife Service, Sacramento, California.

Berry, K. H. and A. P. Woodman. 1984. Methods used in analyzing mortality data

for most tortoise populations in California, Nevada, Arizona, and Utah.

Appendix 7 In: The Status of The Desert Tortoise (Gopherus agassizi) in

the United States. (K. H. Berry, ed.). Report from the Desert Tortoise

Council to the U.S. Fish and Wildlife Service, Sacramento, California.

Burge, B. L. 1977. Aspects of the ecology of the desert tortoise, Gopherus

agassizi, at the Goffs site, eastern Mojave Desert, San Bernardino County,

California. Report to the Bureau of Land Management, Riverside District Office.

Burge, B. L. 1980. Study of the desert tortoise, Gopherus agassizi, at the

Goffs plot, spring, 1980. Report to the Bureau of Land Management,

Riverside District Office.

California Department of Water Resources. 1981. Index to Sources of

Hydrologic Data. Bulletin 230-81. 695 pp.

Delury, D. B. 1958. The estimation of population size by a marking and recapture procedure. J. Fish. Res. Bd. Canada 15: 19-25.

Gibbons, J. W. and J. L. Greene. 1979. X-ray photography: a technique to determine reproductive patterns of freshwater turtles. Herpetologica 35: 86-89. 
' 
Hohman, J. and R. D. Ohmart. 1980. Ecology of the desert tortoise (Gopherus agassizii) on the Beaver Dam Slope, Arizona. Report to the U.S. Bureau of Land Management, Riverside District Office.

Lampkin, W. H. 1966. Hatching tortoise eggs. Int. Turtle and Tortoise Soc. J. 1: 4-5.

Legler, J. M. 1960. Natural history of the ornate box turtle, Terrapene ornata ornata Agassiz. Univ. Kans. Publs. Mus. Nat. Hist. 11: 527-669. Marlow, R. W. and K. Tollestrup. 1982. Mining and exploitation of natural mineral deposits by the Desert tortoise, Gopherus agassizij. Anim. Behav. 30: $475-478$.

Mertz, W. 1981. The essential trace elements. Science 213: 1332-1338. Schneider, P. B. 1980. A comparison of three methods of population analysis of the desert tortoise, Gopherus agassizi. pp. 156-162 In: Proc. 1980 Symposium, Desert Tortoise Council (K. A. Hashagen, ed.). Schumacher, F. X. and R. W. Eschmeyer. 1943. The estimation of fish populations in lakes and ponds. J. Tenn. Acad. Sci. 18: 228-249. Shields, T. A. 1980. A method for determination of population structure and density of the desert tortoise. pp. 151-155 In: Proc. 1980 symposium, Desert Tortoise Council (K. A. Hashagen, ed.). Sokol, 0. M. 1971. Lithophagy and geophagy in reptiles. J. Herpetol. 5: $69-71$.

Tinkle, D. W., J. D. Congdon and P. C. Rosen. 1981. Nesting frequency and success: implications for the demography of painted turtles. Ecology 62: $1426-1432$.

Tomko, D. S. 1972. Autumn breeding of the desert tortoise. Copeia 1972: 895. 

Turner, F. B., P. A. Medica and C. L. Lyons. 1984. Reproduction and survival of the desert tortoise (Scaptochelys agassizii) in Ivanpah Valley, California. Copeia 1984 (in press).

Turner, F. B., C. G. Thelander, D. C. Pearson and B. L. Burge. 1984. An evaluation of the transect technique for estimating desert tortoise density at a prospective power plant site in Ivanpah Valley, California. pp. In: Proc. 1982 Symposium, Desert Tortoise Council (K. A. Hashagen, ed.).

Wilbur, H. M. 1975. The evolutionary and mathematical demography of the turtle Chrysemys picta. Ecology 56: 64-77.

Woodbury, A. M. and R. Hardy. 1948. Studies of the desert tortoise, Gopherus agassizii. Ecol. Monogr. 18: 145-200.

Woodman, A. P. and K. H. Berry. 1984. A description of carcass deterioration for the desert tortoise and a preliminary analysis of disintegration rates at two sites in the Mojave Desert, California. Appendix 6 In: The Status of The Desert Tortoise (Gopherus agassizi) in the United States. (K. H. Berry, ed.). Report from the Desert Tortoise Council to the U.S. Fish and Wildlife Service, Sacramento, California. 

Appendix 1

Estimated cover and frequency of annual plants (Transect I) in Plot 1, 1980 and 1983

Species Cover $\left(\mathrm{cm}^{2} / \mathrm{m}^{2}\right)$ Relative cover Frequency Relative

frequency $(\%)$

$\begin{array}{llllllll}1980 & 1983 & 1980 & 1983 & 1980 & 1983 & 1980 & 1983\end{array}$

$\begin{array}{lllllllll}\text { Schismus } & 2070 & 2316 & 76.2 & 91.5 & 1.00 & 1.00 & 26.6 & 34.7\end{array}$

\section{barbatus}

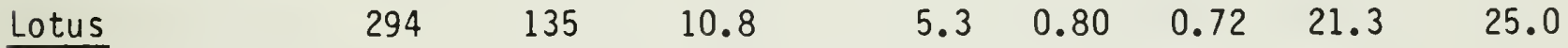

tomentellus

\begin{tabular}{lrrrrrrrr} 
Borages & 122 & 34.8 & 4.5 & 1.4 & 0.56 & 0.28 & 14.9 & 9.7 \\
Erodium & 48.1 & 6.8 & 1.8 & 0.3 & 0.24 & 0.12 & 6.4 & 4.2 \\
\hline
\end{tabular}

\section{cicutarium}

$\frac{\text { Astragalus }}{\text { didymocarpus }}$

Lepidium lasiocarpum

$\begin{array}{llllllll}12.0 & 8.4 & 0.4 & 0.3 & 0.04 & 0.16 & 1.1 & 5.6\end{array}$

Eschscholtzia $\quad 10.0$

$67.2 \quad 10 \quad 2.5$

$0.4 \quad 0.24 \quad 0.20$

6.4

6.9 minutiflora

Eriophyllum

23.6

$17 \quad 0.4$

$0.7 \quad 0.16$

0.28

4.3

9.7 wallacei

Eriogonum spp. $\quad 46.0$

0.9

$-\quad 0.20$

5.3

Allionia incarnata

Others

23.6

0.6

0.8

$-\quad 0.24 \quad 0.08$

6.3

2.8

Totals

$2716 \quad 2531$

100

10

$\begin{array}{lll}3.76 \quad 2.88 & 100\end{array}$ 

Appendix 2

Estimated standing crops $\left(\mathrm{g} / \mathrm{m}^{2}\right)$ of annual plants along two transects in Plot 1 during 1983

Species

April Transect I $\begin{gathered}\text { May } \\ \text { October April Mansect II }\end{gathered}$ October

Astragalus didymocarpus
0.05
0.20

0.02

0

Chorizanthe brevicornu

$0.02 \quad 0.10$

0.08

0.50

Cryptantha angustifolia

$0.07 \quad 0.02$

0.23

0.02

C. circumscissa

$0 \quad 0$

0.08

0.10

Eriogonum trichopes

$0.03 \quad 0.11$

0.04

0.23

Eriophyllum pringlei

$0 \quad 0$

0.37

0.43

E. wallacei

$<0.01 \quad 0.01$

0.17

0.05

Erodium cicutarium

$0.13 \quad 0.13$

$<0.01 \quad 0$

Eschscholtzia minutiflora

$0.53 \quad 1.07$

0.02

0

Lepidium lasiocarpum

$1.27 \quad 1.29$

0.21

0.05

Lotus tomentellus

$3.57 \quad 7.60$

0.12

0

Lupinus concinnus

$0.21 \quad 0$

0.67

0.26

Pectocarya spp.

$0.42 \quad 0.54$

13.55

5.18

Schismus barbatus

$31.20 \quad 16.27$

$24.22 \quad 5.25$

Stylocl ine micropoides

$<0.01<0.01$

$0.21 \quad 0.08$

Others

$0.13 \quad 0.11$

0.06

0.11

Totals

$37.7 \quad 27.5$

22.0

40.1

12.3

10.7 



\section{Legal Notice and Acknowledgments}

\section{Legal Notice}

This report was prepared as an account of work sponsored by the United States Government and the Southern California Edison Company. Neither the United States nor the United States Department of Energy nor the United States Bureau of Land Management, or their employees, nor any of their contractors, subcontractors or their employees, makes any warranty, express or implied, or assumes legal liability or responsibility for the accuracy, completeness or usefulness of any information, apparatus, product or process disclosed, or represents that its use would not infringe on privately owned rights.

\section{Acknowledgments}

We thank Byron Mechalas, John Palmer and Terry Sciarrotta of Southern California Edison Company; Wesley Chambers, Larry Foreman, Gerald Hiller and William Radtkey of the'U.S. Bureau of Land Management; Tanya Crenovich, Philip Costic, and Juanita Lewis of the University of California, Los Angeles; and Auda Morrow of the Civil Effects Test Operations at the Nevada Test site, for indispensable assistance with the planning and conduct of this work. Gary Breitenbach, Just in Congdon, Whitfield Gibbons, Philip Medica, Kenneth Nagy, Paul Schneider, and Ian Swingland provided valuable technical advice and recommendations. Thomas Patin of the Leo Rigler Center for Radiological Sciences at UCLA, Richard Rosen and Michael Gerardo gave technical 

advice regarding radiography. Meane Novak, I).V.I1., permitted the use of nis radiation facilities in Rermuda City and the development of $x$-ray nlates in his labnratory. !le thank ilr. and ilrs. ilorris Sivain and Troy Sivain, of Canffs, for their support during the field work and for permission to use our $x$-ray llachine at their store. Robert Hood gave advice regarding preparation of soil samples for spectrographic analysis and Leon licAnulty made the analyses. Finally, we are iarticularly grateful to the individuals who carried out the field work and in rovided the hackhone of the operation at foffs: Thomas Ackerman did the Samplinn of annual plants; Jan Rickett, Retty Rurge Reck, Page Hayden and Lnri licholson Humphreys Morked with tortoises; Russell Reck, llark Dodero and Alton Dherson volunteered services for short perinds during the season. Ue thank Mmy inhert.s for typing and secretarial assistance. This rork was supported by a contract (C0503915) hetween Southern California Edison Company and the "niversity of California, hy a Memorandum of Inderstanding and Purchase Urder (C.136.3901) hetween Snuthern California Edison Company and the Eureau of I.and i'anagement, and by Contract nE-AinO3-76-SFnno12 between the U.S. Department of Energy and the University of California. 


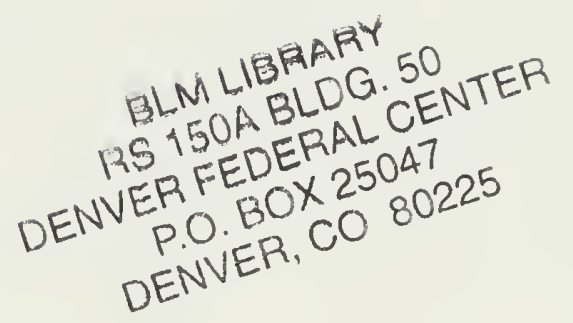




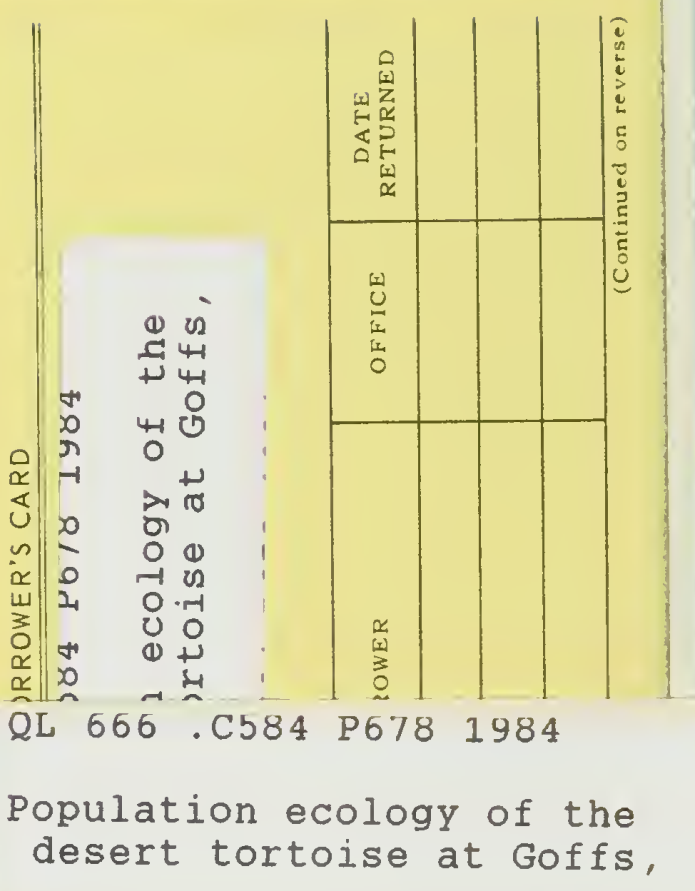

BLMLIS:-AMYY RS 150 A BLDG. 50
DENVER FEDERAL CENTER P.O. BOX 25047 DENVER. CO 80225 
